Cuadernos de Historia Moderna

ISSN: 0214-4018

https://dx.doi.org/10.5209/chmo.78387

\title{
La carrera episcopal bajo el régimen del real patronato (1523-1834). Perfiles sociales
}

\author{
Maximiliano Barrio Gozalo ${ }^{1}$
}

Recibido: 13 de marzo de 2021 / Aceptado: 13 de octubre de 2021

Resumen. A través de la documentación vaticana y los archivos nacionales, presento una breve síntesis de dos aspectos de los obispos españoles, de 1523 a 1834. Primero, analizo las provisiones episcopales, y después examino los aspectos sociales de los electos.

Palabras clave: Obispos españoles; España Moderna; elite de poder; carrera episcopal.

\section{[es] The episcopal career under the regime of the Royal Patronage (1523- 1834). Social profiles.}

\begin{abstract}
Through Vatican documentation and the national archives, I present a brief synthesis of two aspects of the Spanish bishops, from 1523 to 1834 . First, I analyze the episcopal provisions, and then I examine the social prolife of the elected.
\end{abstract}

Keywords: Spanish bishops; Modern Spain; Power elite. Episcopal career.

Sumario: Las provisiones episcopales. Criterios regios para el nombramiento de los obispos. La mecánica de los nombramientos. La carrera episcopal. Aspectos sociales de los electos. La edad de nombramiento. El reclutamiento regional. Un mundo social diverso. La formación. La experiencia previa. La duración de los pontificados y su término. Duración de los pontificados. El término de la carrera episcopal. Bibliografía.

Como citar: Barrio Gozalo, M. (2021). La carrera episcopal bajo el régimen del real patronato (15231834). Perfiles sociales, en Cuadernos de Historia Moderna, 729-762.

En las últimas décadas la historiografía ha dado pasos de gigante en el estudio de los integrantes de distintas instituciones desde una perspectiva fundamentalmente social, reuniendo información sobre los titulares que ocupan los diversos cargos: datos de naturaleza familiar, cultural, religiosa, política y económica, a fin de trazar una biografía colectiva que permita aproximarnos a una sociografía retrospectiva de un determinado grupo social, y ello se ha traducido en la publicación de diferentes

\footnotetext{
$1 \quad$ Universidad de Valladolid ORCID: https://orcid.org/0000-0001-8677-9577

Email:maxibarrio@hotmail.com
} 
estudios sobre la historia social de la administración y de algunos grupos sociales ${ }^{2}$. Es cierto que la historia social del clero español ha estado olvidada mucho tiempo, pero en las últimas décadas han visto la luz muchos estudios sobre el estamento eclesiástico que, sin pretender hacer la historia social del clero, aportan numerosa información para su construcción, siendo la jerarquía eclesiástica la que cuenta con estudios más completos ${ }^{3}$.

Dejando a un lado las causas por las que la historia social de la Iglesia española ha tardado tanto en despegar, en las páginas siguientes intento hacer una breve exposición de la carrera episcopal. Después de analizar las provisiones episcopales, estudio los aspectos sociales de los obispos que rigen las diócesis españolas desde 1523, en que el papa Adriano VI concedió al Carlos I el derecho de patronato y de presentación, hasta la muerte de Fernando VII (1833), puesto que su poder económico, social, moral, cultural y, a veces, también político los convirtió en una de las elites más poderosas de la ciudad episcopal y de su diócesis, que es lo mismo que decir de los antiguos reinos de España. Y concluyo con el examen de la duración de los pontificados y su término.

\section{Las provisiones episcopales}

Los príncipes renacentistas intervienen en las provisiones episcopales por el interés político-religioso que su control aporta a su poder. En España los Reyes Católicos luchan desde el inicio de su reinado por conseguir el derecho de presentación, aduciendo el derecho de patronato, y lo consiguen para los obispados del reino de Granada, Canarias y las iglesias de las Indias, pero para las demás iglesias peninsulares la Curia romana solo les reconoce el derecho de suplicación, muchas veces violado. Más éxito tuvo Francisco I, al conseguir en el concordato de 1516 que León X le concediera el derecho de nombrar y presentar para todas las iglesias y abadías del reino de Francia, a excepción de las vacantes en Curia o las que tuviesen privilegio especial para elegir a sus prelados ${ }^{4}$. Esta concesión sirvió de estímulo a los monarcas españoles para luchar por conseguir el derecho de presentación que venían demandando desde años atrás. Por ello, en el umbral del reinado de Carlos I, el licenciado Ruiz de Villegas dice que "el nuevo monarca debía empeñarse en conseguir para los reyes de España el derecho de patronato y de presentación para todas las dignidades

Fernández, R.: "Historia social. Historia en construcción. Una década de Historia Social en el modernismo catalán", en Martínez Shaw, C. (ed.): Historia moderna. Historia en construcción, Lleida, Milenium, 1999, vol. 2, pp. 7-54, ofrece un balance historiográfico sobre este tipo de estudios.

3 Entre los muchos trabajos publicados me limito a citar algunos de Barrio Gozalo, M.: "La jerarquía eclesiástica en la España Moderna. Sociología de una elite de poder (1556-1834)", Cuadernos de Historia Moderna, 25 (2000), pp. 17-59; "Sociología del alto clero en la España del siglo ilustrado", Manuscrits, 20 (2002), pp. 29-59; "Estudio socioeconómico de los obispos de Canarias durante el Antiguo Régimen (1556-1834)", Anuario de Estudios Atlánticos, 48 (2002), pp. 1-69; "Perfil socio-económico de los obispos del reino de Valencia durante el Antiguo Régimen (1556-1834)”, Anthologica Annua, 50 (2003), pp. 311-371; El Real Patronato y los obispos españoles del Antiguo Régimen (1556-1834), Madrid, Centro de Estudios Políticos y Constitucionales, 2004; "Los obispos de Cataluña durante el Antiguo Régimen (1556-1834)", Anthologica Annua, 53-54 (2006-2007), pp. 377-527; etc. También resulta de gran interés la obra de Artola Renedo, A.: De Madrid a Roma. La fidelidad del obispado en España (1760-1833), Gijón, Trea, 213.

4 Mercati, A.: Raccolta di concordati su materie ecclesiastiche tra la Santa Sede e le Autoritá Civili, Città del Vaticano, Tipografia Poliglotta Vaticana, 1954, vol. 1, pp. 233-251. 
y beneficios que suelen ser provistos por el Papa, y sin perjuicio de la media anata debida al mismo pontífice"s.

El rey Carlos siguió la política de sus abuelos: trató de imponer su voluntad en las provisiones y luchó por conseguir el derecho de presentación, pero tuvo que esperar al pontificado de Adriano VI (1522-1523) para que se hiciera realidad. El 28 de mayo de 1523 le concedió el derecho de patronato y de presentación para la iglesia de Pamplona, aunque vacase en la Curia romana ${ }^{6}$; y, poco después, cuando ya estaba en el lecho de muerte y sin poder consultar a los cardenales, con la bula Eximie devotionis affectu (6-IX-1523) aprobó y confirmó cualquier concesión de patronato y presentación hecha a los reyes anteriores, y otorgó al rey Carlos y sus sucesores en las coronas de Castilla y Aragón el derecho de patronato y de presentación de personas idóneas a las iglesias catedrales y monasterios consistoriales, excepto cuando vacasen en la Curia?.

Clemente VI (1523-1534) comenzó su pontificado respetando la expedición de la bula de Adriano VI, que le fue presentada por el datario Enckewort, obispo de Tortosa, y el Emperador empezó a presentar obispos para las iglesias que iban vacando. En los años 1524 y 1525 la Curia dio el pase a un buen número de nombramientos, pero algunos cardenales se mostraron disconformes con el privilegio adriano y se organizó una fuerte oposición contra la bula, que se agudizó en 1526 cuando surgieron las primeras diferencias entre el Papa y el Emperador en la política italiana e internacional, y consiguieron su revocación en el consistorio del 3 de abril de 1527, cuando el ejército imperial avanzaba hacía Roma ${ }^{8}$. Como consecuencia de esta situación se bloquearon la mayor parte de las provisiones en los años 1526-1528, aunque el embajador imperial consiguió que el Papa pasara algún nombramiento sin hacer mención al derecho de presentación.

Firmada la paz de Barcelona en 1529, mientras el Emperador preparaba su viaje a Bolonia para la coronación imperial, el embajador Miguel Mai inició las negociaciones para la confirmación de la bula adriana y, a pesar de la oposición de la Curia, "que me hacen perder la paciencia con las nuevas dificultades que ponen cada hora porque les toca al vivo y sáleles del alma", lo consiguió con la bula Etsi ea quae, fechada en Bolonia el 11 de enero de 1530. En ella el papa Clemente VII aprueba, renueva y confirma las concesiones de sus antecesores y, de acuerdo con los cardenales, concede al Emperador y sus sucesores el derecho de patronato y presentación de personas idóneas a las iglesias catedrales y monasterios consistoriales de los reinos de las coronas de Castilla y Aragón, aun en el caso de quedar vacantes en la Curia romana por muerte de los cardenales.

Aunque la bula de Clemente VII parecía definitiva, en los primeros años del pontificado de Paulo III (1534-1549) surgieron de nuevo vacilaciones a la hora de su aplicación y se llegó al enfrentamiento en la provisión de Jaén ${ }^{10}$. Por ello, el Papa

Copia del "Memorial del licenciado Pedro Ruiz de Villegas a Carlos I. Valladolid, 23 de noviembre de 1516", en Brandi, K.: "Beriche und Studien zur Geschichte Karl V", Nachrichten von der Akademie der Wissenschaften in Göttingen, 9 (1941), pp. 168-181.

6 Azcona, T. de: "Derecho de patronato y de presentación a la iglesia de Pamplona. Privilegio de Adriano VI a Carlos V en 1523", Scripta Theologica, 16 (1984), pp. 499-542.

La bula original se encuentra en el Archivo General de Simancas (AGS), Patronato Real, 38-36.

Archivio Apostolico Vaticano (AAV), Arch. Concist., Acta Vicecanc., vol. 3, fol. 144.

AGS, Estado, leg. 853, fol. 128.

AGS, Patronato Real, 38-25. 
firmó el 7 de julio de 1536 la más amplia y definitiva concesión beneficial, confirmando las bulas de Adriano VI y Clemente VII y concediendo al Emperador y sus sucesores el derecho de patronato y presentación de todas las iglesias catedrales y monasterios consistoriales, aunque vacasen en la Curia romana. Con estas concesiones pontificas, más las hechas anteriormente para las iglesias del reino de Granada, Canarias, América y Pamplona, se coronó el esfuerzo de los monarcas por conseguir el control de las provisiones episcopales, tanto por motivos políticos y económicos como religiosos.

Por la concesión del derecho de presentación la Santa Sede se obligaba a aceptar, si eran idóneos, a los candidatos presentados por los reyes, pero no graciosamente como en la suplicación, sino a título oneroso, originado por el patronato. Por esta razón Felipe II podía decir en 1556 que "por derecho, antigua costumbre y justos títulos y concesiones, somos patronos de todas las iglesias catedrales de estos reinos, y nos pertenece la presentación de los obispados y arzobispados, prelacías y abadías consistoriales de estos reinos, aunque vaquen en la Corte de Roma"'11. El nuevo régimen de las provisiones episcopales, acercándolas en la doctrina y en la práctica a los intereses de la Corona, originó un episcopado nuevo, predispuesto a una singular visión del Estado y a la colaboración con el mismo.

\section{Criterios regios para el nombramiento de los obispos}

La provisión de los obispados durante el periodo estudiado discurre por los cauces marcados por los Reyes Católicos, precisados más tarde por Felipe II en la Instrucción de $1588^{12}$, donde se indican los criterios que se debían seguir en las provisiones, que en buena medida coinciden con las preguntas que se hacen a los testigos en el primer interrogatorio del proceso consistorial, donde se pide información sobre el lugar de nacimiento, legitimidad y edad del candidato, si está ordenado in sacris, vida, fama y costumbres, titulación universitaria, cargos desempeñados, si tiene algún defecto corporal o espiritual o algún impedimento canónico que le impida ser obispo, y si le cree digno para esa dignidad ${ }^{13}$. A través de estas disposiciones y las consultas del Consejo se pueden sintetizar las cualidades exigidas a los electos en tener la edad requerida, ser naturales de estos reinos y honestos, estar graduados en las facultades de teología o cánones, ordenados in sacris, hijos de legítimo matrimonio y tener experiencia de gobierno ${ }^{14}$.

La edad mínima que exigen los cánones para acceder a un obispado son treinta años, y el examen de los seleccionados para sedes episcopales muestra que la casi totalidad de los electos son hombres en plena madurez vital, venerables ancianos para la concepción de la época, pues los 52 años y medio que se registran como media general de los más de tres siglos que se analizan, no dejan lugar a dudas respecto a las condiciones de madurez y responsabilidad que se quieren exigir a los electos para

\footnotetext{
Novísima Recopilación de las leyes de España, Madrid, 1805, libro 1, tít. 17, ley 4.

12 Instrucción que debe observar la Cámara en las consultas para la provisión de prelacías (...), de 6 de enero de 1588, que pasó a integrar la ley 11, tít. 17, libro 1 de la Novísima Recopilación.

13 Las preguntas del interrogatorio que se hace a los electos de primera provisión apenas varía a lo largo de todo el periodo estudiado. Cf. Rizler, R.: "Procesos informativos de los obispos de España y sus dominios en el Archivo Vaticano", Anthologica Annua, 4 (1956), pp. 465-498.

14 Barrio Gozalo, op. cit. (nota 3, 2004), pp. 44-156.
} 
sedes episcopales. Solo se encuentran algunos miembros de la familia real que tienen que ser dispensados por defecto de edad.

El análisis de la procedencia geográfica de los obispos refleja con precisión la estructura de la Monarquía y el mayor peso de Castilla dentro de la misma, sin olvidar la incidencia que los decretos de Nueva Planta tuvieron en este punto, al poner fin al privilegio de extranjería. Los reyes ponen interés en proveer los obispados en personas naturales de sus reinos, aunque esto se aplicó de forma distinta en Castilla que en Aragón, como luego se verá.

La honestidad como signo de perfección personal y vehículo de ejemplaridad del pueblo cristiano fue una de las constantes que, en líneas generales, mantuvieron los reyes como criterio de elección, y que la reforma tridentina concretizó en la figura del buen pastor que cuida de sus ovejas y las gobierna con caridad; es decir, junto con la función magisterial, debe brillar la santificadora y de gobierno, que se desarrolla en el ejercicio de la caridad y en la asistencia a los necesitados, en la administración de la justicia, provisión de beneficios y sobre todo en la visita pastora ${ }^{15}$. No obstante, algunos obispos caen en la tentación de engrandecer sus casas y familias, levantando palacios y fundando mayorazgos, y no faltan "unos pocos avarientos prelados, tan faltos de caridad, que no solo dejan padecer extremas necesidades a los pueblos de su cargo y morir de hambre a las ovejas que esquilman, sino que ni aun por dinero quieren venderles el trigo que necesitan"16.

Otro de los criterios regios para la provisión de los obispados es que estén graduados en teología o cánones por universidades aprobadas. Y el análisis de la formación cultural de los electos pone de manifiesto que casi todos han cursado estudios superiores, alcanzado los grados de doctor, licenciado, bachiller o maestro. La mayoría en las universidades y algunos miembros del clero regular en los centros de su religión, que luego analizaré.

El requisito de estar ordenado in sacris se observa en casi todas las provisiones, aunque se encuentran algunas excepciones, sobre todo en miembros de la familia real que aceden al episcopado. Menor rigor se aprecia en la exigencia de ser hijo de legítimo matrimonio, sobre todo en el caso de miembros de la realeza y de la alta nobleza. Pero este fenómeno, frecuente en los siglos XVI y XVII, en la siguiente centuria prácticamente desaparece.

Las consultas de la Cámara de Castilla y, más aún, los pareceres del confesor real presentan como un elemento importante para ser electo la experiencia profesional anterior y haber desempeñado cargos de gobierno. El análisis de los cargos previos de los electos pone de manifiesto que los canales que confluyen en su elección provienen fundamentalmente de los cabildos catedrales, sobre todo canónigos de oficio; del mundo inquisitorial: consejeros de la Suprema e inquisidores; de la burocracia cortesana: presidentes, regentes y oidores de las Chancillerías y Consejos; y de la burocracia eclesiástica: vicarios generales y provisores, obispos auxiliares, auditores de la Rota, etc. También están presentes, pero en menor proporción, los catedráticos de Universidades y Seminarios, los confesores de la familia real y, en menor medida, los párrocos. Y, por último, están los religiosos que desempeñan cargos de gobierno en sus institutos.

Tellechea, J. I.: El Obispo ideal en el siglo de la Reforma, Roma, Iglesia Nacional Española, 1963, pp. 126-140 y $179-191$.

16 Castillo de Bobadilla, J.: Política para corregidores y señores de vasallos, en tiempos de paz y de guerra, y para jueces eclesiásticos..., II, Madrid, Imprenta Real, 1775, libro III, cap. $3^{\circ}, \mathrm{n}^{\circ}$ 15, p. 27. 
La condición de noble, aunque no se requería, tenía gran peso en las provisiones episcopales, tanto por el favor que gozaban en la Corte como porque habían acaparado las becas de los Colegios Mayores, de forma que los obispos de origen noble representan la mayoría de los prelados que rigen las diócesis españolas en el periodo estudiado. Fenómeno que se repite con mayor intensidad en otros países católicos de Europa, cuyos obispos provienen mayoritariamente de la aristocracia hasta finales del Setecientos ${ }^{17}$.

Estos criterios mantienen su validez durante todo el Antiguo Régimen, aunque en su etapa final el factor político, entendido en un sentido muy general, se decanta como un componente esencial de ciertos nombramientos, si bien es verdad que muchas veces resulta difícil separarlo de intereses más o menos personalistas, como son la subjetividad afectiva y los influjos cortesanos.

Esta es la teoría, pero ¿quién recomienda al candidato? El hecho de que el aspirante a un obispado no pueda pedirlo directamente, sino que deba procurarse el favor de intermediarios bien situados en la Corte favorece la inserción de muchos obispos en las redes clientelares y facciones cortesanas. La virtud y el mérito por sí solas no convierten a un individuo en candidato a una mitra si nadie le recomienda a la Cámara o al monarca, pues como dice Bermúdez de Pedraza en 1643, "ninguno es de tan claro ingenio que pueda lograr la mitra si le falta la materia, la ocasión, el padrino y la recomendación"18. En la segunda mitad del Seiscientos, quizá por la debilidad del monarca, la fuerza de la recomendación y de los lazos familiares se acentúan considerablemente, hasta el punto de que el obispo de Solsona dice al rey en 1694 que, cuando vaca algún cargo u obispado, las más de las veces no se tiene en cuenta quién puede desempeñarlo con mayor acierto, sino quién nació mejor o tiene las recomendaciones más grandes y poderosas, "cuando solo habría que considerar quién es el más idóneo para cumplir bien con el cargo, no cediendo a la presión de la recomendación ni del nacimiento" ". Sobre la decisión de la Cámara y del monarca pueden incidir numerosas consideraciones. Desde las más altas motivaciones espirituales hasta los más cotidianos intereses. Todo puede influir y a veces lo hace contemporáneamente, bien entendido que también tiene gran peso la calidad del candidato. Por tanto, para acceder a la carrera episcopal, sin infravalorar estos aspectos, aparecen tres factores determinantes: la familia, los lazos de clientela y el mérito.

La reconstrucción de un buen número de carreras episcopales permite resaltar la importancia que tiene la familia para conseguir una mitra. No se trata de algo nuevo, pues las maniobras de los poderosos por obtener un obispado para alguno de sus hijos son bien conocidas. La documentación muestra el carácter general del fenómeno. Detrás de muchos obispos está una familia dispuesta a sostenerlo y a interceder en su favor, y no es raro que algunos dejen la sede a sus hijos o sobrinos, pues un buen número de obispados parece que estaban reservados total o parcialmente a determinadas familias nobles. Es verdad que después del concilio de Trento ya no se encuentran obispos que dejen la sede a sus hijos o sobrinos (aunque se da algún caso), pero continúa siendo frecuente encontrarnos con auténticas dinastías episcopales, como

17 Péronet, M.: Les Èveques de l'ancienne France, Lille, Université Lille III, 1977, p. 535; y Müller, W.: “L'episcopat polonais à l'epoque post-tridentine", en Vogler, B. (ed.): L'institution et les provoirs dans les églises de l'antiquité a nos jours, Bruxelle - Louvain, Éditions Nauwelaerts, 1987, p. 374.

18 García Marín, J.: La burocracia castellana bajo los Austrias, Sevilla, Instituto García Oviedo, 1976, p. 193.

19 "Representación que el obispo de Solsona dirige a Carlos II en 1694”, en Valladares, A.: Semanario Erudito, Madrid, Blas Román, 1789, XX, p. 265. 
los Sandoval, los Santos de San Pedro y otros más. El famoso nepotismo no afecta solo a la Curia romana, sino que se encuentra en todos los países, quizá porque es algo congénito a la sociedad del Antiguo Régimen. Algo similar ocurre con el fenómeno de la clientela, entendido en un sentido muy amplio, como redes de cooptación, pues en la carrera de un obispo difícilmente deja de apreciarse la intervención de personas influyentes, ya que contar con un protector poderoso sigue siendo igual de importante en el siglo XVI que en el XVIII.

La fuerza de los lazos familiares, la continuidad de las relaciones de clientela son instrumentos del pasado que continúan condicionando la promoción a una mitra. Entonces, ¿qué ha cambiado en un mundo en el que la recomendación tiene tanto peso y el mérito personal tan poco? En lo que respecta al nombramiento de obispos mucho, porque Felipe II, aunque se muestra receptivo a las recomendaciones que recibe, se reserva siempre la última palabra en las presentaciones y, en general, los obispos nombrados durante su reinado fueron virtuosos, cultos y competentes. Cabrera de Córdoba, quizá con un poco de exageración, dice que les nombraba con gran cuidado, a fin de que los fieles los reverenciasen por su virtud, trabajo, edificación, gobernación pacífica y preparación cultural. "Prefería la virtud al nacimiento, aunque en caso de igualdad se pronunciaba por los nobles y los deudos de sus amigos y ministros" ${ }^{\text {"20. }}$.

El papa Clemente VIII, que estaba bien informado por el nuncio Caetani de la política seguida por el monarca, "de haber nombrado siempre para los obispados a personas insignes por sus letras y costumbres" 21 , al conocer su muerte ratifica estas opiniones y afirma que "ninguno supo jamás hacer mercedes con tanta igualdad y repartir lo que Dios le había dado tan bien, como se pareció en las provisiones y presentaciones de las iglesias y obispados"22.

Poco después de morir Felipe II, el nuncio Caetani presentó a Felipe III un memorial recordándole la obligación de elegir buenos prelados como había hecho su padre, "proveyendo las iglesias de hombres y no los hombres de las iglesias". Es decir, no dar las iglesias a instancia de gente interesada, sino informándose previamente de personas honradas y religiosas ${ }^{23}$. Y en cierto modo Felipe III y los monarcas del siglo XVII siguieron la política del rey prudente en las provisiones, aunque la intervención de los válidos y las influencias cortesanas devaluaron un poco el sistema, como se puede apreciar por el elevado número de hijos ilegítimos del rey y de la alta nobleza que accedieron al episcopado en este siglo.

Después de la revuelta catalana (1640-1653), la fidelidad al monarca se convirtió en requisito imprescindible para ocupar sus sedes. En Tarragona porque era la primera iglesia del Principado y su titular presidente del brazo eclesiástico en las Cortes; en Barcelona porque era la capital política y convenía que sus prelados fueran sujetos de calidad y experiencia, como indica el Consejo de Aragón en la consulta de 1653 al proponer a Ramón Sentmenat:

Persona de conocida sangre y muy principal en Cataluña. Su celo y atención al servicio de V. M. le sacó del Principado desde el tiempo de las alteraciones, y en

\footnotetext{
Cabrera de Córdoba, L.: Historia de Felipe II, Rey de España, II, Madrid, Sucesores de Rivadeneyra, 1876, pp. 763-764.

21 AAV, Segr. Stato, Spagna, 49, fol. 285.

22 Cabrera de Córdoba, op. cit. (nota 20), II, p. 767.

23 AAV, Fondo Borghese, Serie III, vol. 74, fols. 555-562.
} 
estos doce años ha padecido grandemente con muchas descomodidades en esta Corte y se ha experimentado su constancia y entereza de ánimo, y juzga el Consejo será muy del servicio de Dios y de V. M. su persona en Barcelona por su virtud, séquito y otras cualidades que le hacen digno de esta iglesia. Además de estar emparentado con lo más ilustre de Cataluña, que es muy importante para la seguridad que se desea y la estimación que ha de ser para sus deudos ver favorecido de $\mathrm{V}$. M. al obispo ${ }^{24}$.

En Urgel, al estar en la raya de Francia y haber en su iglesia algunos capitulares francófilos y otros que suscitaban continuamente pleitos y discordias contra el prelado, el Consejo indica que convenía poner por obispo un sujeto que, además de virtud y buenas cualidades, tenga valor para moderar y evitar los disturbios, que no tenga deudos en Cataluña, sea afecto al rey y no tenga intereses particulares para poder actuar con la entereza de ánimo que se requería ${ }^{25}$. Razones similares se aducen a la hora de presentar candidatos para las restantes diócesis catalanas y sobre todo para Vic, especialmente conflictiva por la beligerancia de sus canónigos y los enfrentamientos sociales que asolaban la comarca. De todas formas, parece que se utilizó un doble criterio a la hora de cubrir sus sedes. Por una parte, su bajo nivel económico hace que algunos obispados catalanes se conviertan en seminario de obispos, mientras que la conflictividad de otros aconseja enviar hombres experimentados en la tarea de gobierno y hábiles para convivir con los poderosos e influyentes cabildos.

A pesar del cambio de dinastía que se produce al inicio del siglo XVIII, el nombramiento de obispos continúa haciéndolo el rey a través de la Cámara, aunque el factor político incide cada vez más en las provisiones. Un factor coyuntural que tuvo gran influencia en los primeros años del reinado de Felipe $\mathrm{V}$ fue la fidelidad al nuevo monarca y la defensa de la nueva dinastía. En muchas consultas de la Cámara $\mathrm{y}$ en los pareceres del confesor real se resalta esta actitud como un mérito añadido ${ }^{26}$. Incluso Macanaz recuerda al monarca, años después, que muchos eclesiásticos, que por sus méritos debían haber sido promovidos al episcopado, no lo habían sido porque se les había achacado injustamente que habían sido desafectos al monarca ${ }^{27}$.

Después de la expulsión de los jesuitas, el haberlos combatido se convierte en una recomendación y el haber simpatizado con ellos en motivo de exclusión. A partir de 1766 no se elige para el episcopado a persona alguna que no fuera conocida como antijesuita y contraria al probabilismo, pero curiosamente casi todos los prelados nombrados en 1766-1767 mueren en la primera diócesis sin promocionar a otra, dando la impresión de que después que sirvieron para el caso jesuítico ya no interesaban al gobierno, probablemente por su cariz antirregalista ${ }^{28}$.

24 Consulta del Consejo de Aragón, 18 marzo 1653, Archivo Histórico Nacional (AHN), Consejos, leg. 19522. Ramón Sentmenat, nombrado obispo de Vic en 1640, fue promovido en 1653 a Barcelona por Felipe IV, pero Roma no le preconizó hasta el 25 de octubre de 1655.

25 Consulta del Consejo de Aragón, 18 marzo 1653, AHN, Consejos, leg. 19753. Se nombra al abad de Montserrat, Juan Manuel de Espinosa, natural de Sevilla, aunque la confirmación pontificia no llegó hasta el 25 de octubre de 1655 .

26 Alcaraz Gómez, J. F.: "Documentos de Felipe V y sus confesores jesuitas. El cursus episcopal de algunos personajes ilustres del reinado", Revista de Historia Moderna, 15 (1999), pp. 13-42.

27 "Representación que Macanaz remite desde Lieja a Felipe V sobre los males de la despoblación de España y otros daños", en Valladares, A.: Semanario Erudito, Madrid, Blas Román, 1788, VII, p. 194.

28 Artola Renedo, op. cit. (nota 3), pp. 84-88. 
Al mismo tiempo, en la segunda mitad del Setecientos se introducen cambios en los criterios sobre el ideal de obispo. Frente al tipo tradicional -promotor del ascetismo, las devociones, la limosna indiscriminada o la defensa del fuero eclesiástico-, se impone ahora un tipo de prelado que, ya por iniciativa propia o por las insinuaciones de la Corte, promueve los intereses públicos y colabora con el gobierno en el desarrollo cultural, asistencial y económico, dando lugar al obispo ilustrado o «jansenista» que prevalece en el último tercio del siglo XVIII. El apoyo de los prelados a la política ilustrada, a juicio de Floridablanca, es grande y se plasma en casas de caridad, hospicios, obras públicas y de ornato, centros de educación, dotación de cátedras y estudios, fomento de la agricultura e industria. Incluso el obispo de Málaga dirige una pastoral al clero de su diócesis para que incite a sus feligreses a la observancia de la ley civil, "pues el vasallo que no obedece al rey en sus leyes y mandatos ofende a Dios gravemente" 29 .

La tendencia a considerar al obispo como un agente gubernamental, del que se esperaba que fuese no solo un celoso pastor sino también un auxiliar político que exhortara al pueblo a la obediencia, se refuerza con los monarcas de la segunda mitad del siglo XVIII y se acentúa todavía más en los años $1814-1833^{30}$. Y ello determinó que el factor político e ideológico aparezca como el componente esencial de los nombramientos que se llevan a cabo en los últimos años del Antiguo Régimen, hasta el punto de que el nuncio Tiberi no puede menos de exclamar en 1829 que "en España se considera a los obispos públicos funcionarios, concediéndoles el traslado a otra diócesis con mayor nivel de renta como recompensa"31.

\section{La mecánica de los nombramientos}

Hasta el año 1523, en que el Emperador consigue el derecho de presentación de los obispados y demás beneficios consistoriales de los reinos españoles, el nombramiento de los obispos lo hace el Papa, aunque normalmente nombra a la persona por la que ha suplicado el monarca o negocian el nombramiento. Conseguido el derecho de presentación, el Emperador nunca dejó de sus manos este derecho en sus ausencias de España, sino que se lo reservó de forma explícita, según consta en la orden de gobierno dejada a los lugartenientes y gobernadores del reino ${ }^{32}$. No obstante, a partir de 1546 se incrementa la intervención personal del príncipe Felipe en la confección de las listas de candidatos que se remiten a su padre, lo que ayuda a comprender que más tarde intervenga de forma tan activa en los nombramientos episcopales ${ }^{33}$.

Desde 1556, en que Felipe II se pone al frente de la Monarquía, el Consejo de la Cámara (organismo restringido del Consejo de Castilla) y el de Aragón se hacen cargo teóricamente de las consultas para la provisión de los obispados de sus demarcaciones, aunque la falta de una normativa clara facilitó la intromisión de diferentes

29 Hernández, J.: La gestión política y el pensamiento reformista del conde de Floridablanca, Murcia, Editum, 1984, pp. 504-506.

30 Barrio Gozalo; M.: "La política vaticana y el nombramiento de obispos en España al final del Antiguo Régimen", en Liberalisme Chretien et Catholicisme Liberal en Espagne, France et Italie dans la premier moite du XIXe siècle, Aix-en-Provence, Université de Provence, 1989, pp. 175-200.

31 Tiberi a Albani, Madrid, 24 de diciembre de 1829, AAV, Segr. Stato, Esteri, vol. 466.

32 AGS, Patronato Real, leg. 26.

33 Azcona, T. de: "El hecho episcopal hispánico en tiempo de Carlos V (1516-1558)", en Revuelta Sañudo, M. y Morón Arroyo, C. (ed.): El erasmismo en España, Santander, Sociedad Menéndez Pelayo, 1986, pp. $269-272$. 
instancias. Esto permite decir a Santiago Riol que reinaba gran confusión en el despacho y expedición de los negocios de patronato hasta 1588, porque la consulta de los obispados dependía del "arbitrio de un secretario que llamaban de iglesia, que unas veces despachaba con los dos consejeros de la Cámara y otras con el confesor, porque no había tribunal destinado para ello"34. Como este sistema no satisfacía a Felipe II, creó una Junta para reformarlo e introducir los cambios necesarios para centralizar la provisión de los oficios eclesiásticos, que se plasmó en la promulgación de la Instrucción del 6 de enero de 1588 sobre las funciones de la Cámara ${ }^{35}$. La Instrucción supuso una racionalización del sistema, aunque el monarca tuvo que recordar en varias ocasiones que todos los negocios referentes al real patronato se resolvieran en la Cámara sin que interviniesen otros tribunales. La nueva normativa pretendía depurar el proceso de selección de candidatos y evitar tanto la influencia excesiva de una sola persona en los nombramientos episcopales, al obligar a reunirse la Cámara para cada consulta, como la confusión que se producía si intervenían todos los consejeros de Castilla, cada uno con sus candidatos preferidos.

A partir de entonces, los únicos encargados de proponer al monarca, vía consulta, las personas idóneas para ocupar las sedes episcopales son el Consejo de la Cámara para la Corona de Castilla y el de Aragón para su demarcación, que para tener un fichero de posibles candidatos despachaban anualmente cartas a los prelados para que informasen con sigilo de las personas más beneméritas e idóneas para ser presentadas a prelacías. La misma Instrucción regula de forma pormenorizada el contenido de la consulta que debía elaborar la Cámara. Primero, tenía que indicar el obispado que había quedado vacante, su anterior titular y el valor, cargas y pensiones de la mitra. Y después, proponer al sujeto que se juzgase más digno para cada cosa, indicando su lugar de nacimiento, edad, virtud, ejemplo, letras, prudencia y experiencia de gobierno, así como los beneficios eclesiásticos que tenía que dejar y el valor de ellos. Cuando para los arzobispados y obispados de más valor se proponía a otros obispos para ser promovidos, "se declarará particularmente la edad y salud que tienen, y cuánto ha que fueron consagrados, y qué iglesias han tenido a su cargo y cómo las han gobernado"36.

En consecuencia, cuando vaca un obispado, la Cámara se lo comunica al monarca y le informa del valor de la mitra, las pensiones que gravan sus rentas y las que se podían imponer, así como de los posibles candidatos. En los territorios de la Corona de Aragón la mecánica es muy similar. Cuando vaca una iglesia el virrey envía al Consejo de Aragón una terna y sus miembros la aceptan o modifican. Votada la propuesta, se comunica al monarca para que haga el nombramiento.

Normalmente el rey se conforma con el dictamen de la Cámara de Castilla y del Consejo de Aragón, aunque no siempre elige al que indican en primer lugar. Incluso, en alguna ocasión, prescinde de los propuestos en favor de otro candidato, bien por iniciativa propia o por influjo del confesor real, que tenía gran influencia en las

34 "Representación sobre el patronato real, que dio motivo a las novedades del año de 1735, dado por don Santiago Riol", en Valladares, A.: Semanario Erudito, Madrid, Blas Román, 1787, VI, pp. 93-94.

35 De los 27 párrafos que contiene la Instrucción de reforma de la Cámara, los números 8 al 12 constituyen la ley 11, tít. 17, libro I de la Novísima Recopilación, con el título de Instrucción que debe observar la Cámara en las consultas a S. M. para la provisión de prelacias, dignidades y prebendas del real patronato.

36 Ibidem. Muchas de las relaciones de eclesiásticos que envían los prelados se encuentran en AHN, Consejos, legs. 17442-17457, etc. 
provisiones episcopales ${ }^{37}$. El rey podía asesorarse de sus consejeros u otras personas, pero en última instancia la provisión de las vacantes dependía de su voluntad, de forma que cuando no necesitaba su información designaba al obispo sin consulta previa o sin tener en cuenta los candidatos propuestos en la consulta, como hace en múltiples ocasiones.

Designada la persona por el rey, la Cámara o el Consejo se lo comunican al electo, que no siempre acepta aduciendo razones de salud, falta de capacidad para desempeñar el cargo o no sentirse llamado al episcopado. Aceptado el nombramiento por el electo, se informa al nuncio para que haga el proceso consistorial sobre las cualidades del candidato y el estado de la iglesia ${ }^{38}$. Acto seguido se expedía al embajador español en Roma un documento de presentación de tal persona para tal obispado con el fin de elevarla a la Curia $^{39}$, donde era examinada por el consistorio de cardenales ${ }^{40}$. Aceptada la provisión en el consistorio, el provisto o su representante abonaba las tasas debidas y la Curia expedía las bulas, que se enviaban a la Corte y, desde allí, al interesado. Cumplimentados los requisitos cortesanos por el electo, se expedían las cartas ejecutoriales para que las bulas tuvieran efecto y pudiera tomar posesión del obispado.

Pero ¿la Curia romana confirma siempre al candidato propuesto por el monarca? Normalmente sí, aunque se encuentran algunas excepciones, sobre todo en los momentos de tensión entre la Monarquía y el Papado. Al inicio del reinado de Felipe II se produce un enfrentamiento con Paulo IV y el pontífice se niega a preconizar a los obispos nombrados por el monarca. Ante ello, Felipe II ordena a los cabildos de sus iglesias que, "no habiendo Su Santidad querido pasar a las personas propuestas para prelados de ellas", los reciban por administradores de las sedes vacantes hasta que sean provistos como tales obispos ${ }^{41}$. Firmada la paz, en septiembre de 1557, volvió la armonía y el Papa confirmó a los electos.

Durante la revuelta catalana de mediados del siglo XVII el desencuentro surge de nuevo. En 1644 quedó vacante la diócesis de Solsona y Felipe IV nombró un nuevo prelado, pero Inocencio $\mathrm{X}$ se negó a confirmarle. De nada sirvió la presión diplomática ni las súplicas del electo, pues la presión francesa ante la Corte romana frenó la provisión de los obispados catalanes durante una década ${ }^{42}$. En los primeros años del siglo XVIII, con motivo de la ruptura de relaciones de Felipe V con la Corte romana, el problema de la confirmación de los obispos se planteó con toda crudeza, porque el papa Clemente XI se negó a preconizar a los nombrados por el monarca,

37 Carlos Morales, C. J. de: "La participación en el gobierno a través de la conciencia regia: fray Diego de Chaves, confesor de Felipe II", en Rurale, F. (a cura di): I religiosi a Corte. Teologia, política e diplomacia in Antico Regime, Roma, Bulzoni, 1998, pp. 131-157; López Arandia, M. A.: "El confesionario regio en la Monarquía hispánica del siglo XVII”, Obradoiro de Historia Moderna, 19 (2010), pp. 249-278; Alcaraz Gómez, op. cit. (nota 26), pp. 13-46; y Jesuitas y reformismo. El padre Francisco Rávago (1747-1755), Valencia, Facultad de Teología, 1995, pp. 185-227; etc.

38 La mayoría de estos procesos se encuentran en el AAV, Arch. Concist., Processus Consist., vols. 1-234.

39 Esta documentación se halla en el Archivo de la Embajada de España ante la Santa Sede, depositado actualmente en el AHN, Santa Sede, legs. 1-7 y 11 (reales cédulas de presentación de los obispados de España de 1556-1603), 90-100 (presentaciones del siglo XVII), 250-274 (presentaciones del siglo XVIII), y 673-707 (presentaciones de 1801-1834).

40 Las actas del consistorio se custodian en el AAV, Arch. Concist., Acta Camerarii, 1- 56.

$41 \quad$ AHN, Consejos, leg. 15248.

42 Discurso político y legal en que se trata del perjuicio que causa S. S. no queriendo pasar las provisiones de los obispados de Cataluña, Biblioteca Nacional de España (BNE), ms. 6148, fols. 131-139. 
alegando que el rey poseía el derecho de presentación por concesión de Roma y, por tanto, suspendía su práctica mientras no le diera la debida satisfacción. Ante esto, la Junta reservada propuso al rey que, si el Papa se obstinaba en no expedir las bulas de provisión, "se eligieran, aprobaran y consagraran los obispos de Españas como se hacía antiguamente". Pero no se llevó a efecto y en ambos campos se comenzó a buscar el acuerdo, y a partir de 1714 el Papa confirmó a todos los electos por el rey ${ }^{43}$.

Por último, en el primer tercio del siglo XIX vuelve a surgir el problema, porque el gobierno de Madrid trató de nombrar obispos adictos a sus ideas y Roma se negó a concederles la institución canónica o confirmación. Esto acaece durante la ocupación francesa (1808-1813) y, sobre todo, en el Trienio liberal (1820-1823), por los informes negativos que el nuncio Giustiniani envía a Roma sobre la doctrina de los electos, a los que acusa de jansenistas y liberales ${ }^{44}$. Con el triunfo del absolutismo en el verano de 1823 se restableció la armonía, pero se volvió a romper después de la muerte de Fernando VII (1833), porque la Corte romana no reconoció a Isabel II por reina de España.

\section{La carrera episcopal}

Las fuentes que posibilitan el estudio de la carrera de los obispos españoles en el periodo estudiado se encuentran fundamentalmente en las distintas series del Archivo Consistorial, que forma parte del Archivo Apostólico Vaticano, sobre todo en las de procesos consistoriales y en las actas consistoriales y misceláneas, completadas en algunos casos con los procesos de la dataría, que se conservan en el fondo de la Dataría Apostólica del mismo Archivo Vaticano. También aportan rica información las consultas de la Cámara de Castilla y del Consejo de Aragón sobre los electos para ocupar las sedes episcopales, que se guardan en los archivos nacionales.

Los procesos consistoriales son una de las fuentes más ricas para su estudio. El proceso consta de dos interrogatorios sobre los que debían declarar tres testigos "en serie y por extenso, sin que se admitan las solas afirmaciones o negaciones en forma concisa y lacónica". El primero versa sobre las calidades del candidato y consta de las trece preguntas siguientes: si conoce al electo, dónde nació, calidad de sus padres, edad que tiene, si esta ordenado in sacris, si ha ejercido las órdenes y frecuenta los sacramentos, si vive católicamente y con pureza de fe, si tiene buenas costumbres y fama, si es grave y prudente, titulación académica y dónde la obtuvo, si ha ejercido cargos y cómo se ha portado en ellos, si tiene algún defecto o impedimento canónico, y si le cree idóneo para ser obispo. En el caso de que el electo fuera ya obispo y se le trasladara a otra sede, el interrogatorio versa sobre el modo en que ha gobernado la iglesia y consta de diez puntos: si conoce al electo, si sabe que recibió la consagración episcopal, cuánto tiempo ha sido obispo de la iglesias que se le traslada, ha residido en su iglesia, ha visitado la diócesis y hecho cumplir los mandatos, ha

43 Fernández Alonso, J.: "Un periodo de relaciones entre Felipe V y la Santa Sede (1709-1717)", Anthologica Annua, 3 (1955), pp. 43-54.

44 Barrio Gozalo, M.: "La lucha por el control de los nombramientos episcopales en España al final del Antiguo Régimen (1808-1834)", Anthologica Annua, 59 (2012), pp. 253-295; Idem: La Santa Sede y los Obispos españoles en el Trienio Liberal y el inicio de la reacción (1820-1825), Roma, Iglesia Nacional Española, 2017, pp. 149-179. 
celebrado pontificales y ejercido las funciones ministeriales, ha gobernado la iglesia con prudencia y caridad, posee la doctrina que se requiere a un obispo, y si le juzga digno para ser trasladado ${ }^{45}$.

El segundo interrogatorio, que trata sobre el estado y las condiciones materiales de la sede para la que había sido presentado, no interesa para el estudio sociológico de los obispos y por ello no me detengo en su análisis. Terminado el proceso, autentificado, sellado y cerrado, se enviaba a la Curia romana, donde era examinado por el consistorio de cardenales. Si se detectaba algún defecto de forma, se hacía un proceso complementario en la misma Curia para evitar que la devolución del primero al nuncio ocasionara una vacante demasiado larga.

La serie de Acta Camerarii está constituida por actas consistoriales de carácter oficial, es decir, notas oficiales sobre los asuntos de los consistorios secretos y públicos en los que se hacía la presentación y nombramiento del electo para una determinada diócesis. A pesar de su brevedad, estas notas aportan interesantes datos históricos. Primero, indican la fecha exacta de la confirmación de los obispos y, por tanto, permiten saber con exactitud el día de su preconización; y segundo, informan de los cardenales protectores o relatores que hacían la propuesta en el consistorio, profesión del electo, diócesis a que pertenecía, cargos que desempeñaba, grados académicos, nombre del obispo predecesor y causa de la vacante, cargas o pensiones que le imponen, etc. La serie de Acta Miscelanea está formada por una colección de documentos consistoriales, pero sin carácter oficial alguno. Generalmente son extractos y copias de las actas consistoriales oficiales hechos con diversos fines ${ }^{46}$.

En segundo lugar, hay que mencionar las consultas de la Cámara de Castilla y del Consejo de Aragón relativas a la presentación de los obispados de las diócesis españolas, antes mencionadas, que se conservan en Archivo Histórico Nacional, Corona de Aragón y General de Simancas, ya que ponen de relieve el criterio que las informaba y normalmente ofrecen un breve curriculum vitae de los propuestos, aparte de revelar la importancia que se concedía al factor económico en las provisiones ${ }^{47}$.

Por último, hay que tener en cuenta la información que ofrecen los volúmenes de la Hierarchia Catholica ${ }^{48}$, que toman la mayor parte de los datos del Archivo Consistorial del Archivo Vaticano, sin olvidar la información que aparece en los episcopologios ${ }^{49}$ y en el Diccionario Biográfico de los Obispos del Real Patronato,

45 AAV, Arch. Concist., Processus Consist., vols. 1-234. Hay un índice alfabético por el nombre latino de las diócesis: Processi Consitoriali. Index Dioecesium, en el que se indica el año en que se incoa el proceso, el volumen y los folios donde se encuentra. Algunos procesos se encuentran también en el fondo Dataria Ap., Processus Datariae, del que también hay índice: Processus Datariae. Index Dioecesium.

46 Las Acta Camerarii, Acta Vicecanc. y Acta Miscellanea se encuentran en el AAV, Arch. Concist.

47 Las consultas de la Cámara de Castilla de los años 1570-1834 se conservan en AHN, Consejos, legs. 15188 a 15531. Las relativas a la provisión de las mitras de la Corona de Aragón de los años 1604-1834 se encuentran distribuidas, sin un orden preciso, en los legs. 18873-18908, 19080, 19927, 19944, 19976 y 49905. Algunas copias se hallan en Archivo de la Corona de Aragón (ACA), Consejo de Aragón, legs. 122-131; y en AGS, Gracia y Justicia, legs. 534, 543 y 544, hay documentación sobre la provisión de obispados para los años 1701-1785; etc. Información sobre este tipo de documentación en Fuente Cobos, C. de la: "La documentación sobre el patronato eclesiástico de Castilla". Hispania Sacra, 47 (1995), pp. 625-679; y Álvarez-Coca, M. J.: "La Corona de Aragón. Documentación en el Consejo y Cámara de Castilla (1707-1834): fuentes en el Archivo Histórico Nacional". Hispania, 49/173 (1989), pp. 895-984.

48 Hierarchia Catholica Medii et Recentioris Aevi, Monasterii, Regensbergianae, 1923-1968, vols. III-VII.

49 Entre los de ámbito general se pueden citar las obras de González Dávila, G.: Teatro Eclesiástico de las Iglesias metropolitanas y catedrales de los reinos de las dos Castillas, Madrid, en la imprenta de Francisco Martínez, Pedro de Horma y Villanueva, Diego Díaz de la Carrera, 1645-1650, 3 vols. El vol. IV no se imprimió hasta 1700; 
que dirijo y está en curso de publicación, así como la múltiple y rica documentación que custodian los archivos episcopales y catedralicios de las diócesis españolas. En el presente estudio me atengo de forma prioritaria a los datos que aporta la documentación vaticana del Archivo Consistorial y a las consultas de la Cámara de Castilla y del Consejo de Aragón, completados y enriquecidos en algunos casos con otros aportes documentales y bibliográficos.

\section{Aspectos sociales de los electos}

Los obispos provenientes del clero secular estudian generalmente en la universidad y muchos obtienen beca en un colegio; si se trata de uno de los colegios mayores su suerte está asegurada, porque su poder era indiscutible. Del colegio muchos concursan a canonjías de oficios en los cabildos catedrales o colegiales, y otros buscan acomodo en la burocracia civil (oidores, fiscales, consejeros, etc.) o en la eclesiástica (provisor y vicario general, auditor, etc.) para dar el salto después a una mitra. Los que proceden del clero regular comportan algunas diferencias, aunque por lo general los electos son seleccionados entre los que han cursado estudios superiores en la universidad o en los centros de su religión, han ejercido la docencia o han desempeñado cargos de gobierno en su religión.

Por otra parte, la carrera episcopal constituye un auténtico cursus honorum en el que se ingresa generalmente por una diócesis pobre y se asciende por antigüedad y méritos a las más ricas. Solo personas de la primera nobleza o excepcionales comienzan su carrera por una de las primeras sedes. De esta forma, la esperanza de ascenso es uno de los motivos de más peso para tratar de mantenerse en la gracia de la Corona, pues los monarcas, a pesar de tener en cuenta los aspectos espirituales, no por eso dejan de valorar los aspectos económicos anejos a la designación o traslado de los titulares de las mitras, manejando los nombramientos como instrumentos de su política estatal. Felipe II lo dice con toda claridad en 1560, cuando negocia con Roma la licencia para vender señoríos eclesiásticos y Pío IV se resiste a darla sin haber obtenido previamente el consentimiento de los obispos implicados.

Los prelados de estos reinos -dice el monarca-, allende de ser nuestros vasallos, dependen de nos en cuanto a su promoción y acrecentamiento. Y que así mismo es cierto que cualquier prelado a quien en un negocio como éste se le pidiere de nuestra parte su consentimiento ha de tener entendido y persuadirse que, si lo da, recibiremos de ello mucho servicio y que será medio muy conveniente para su promoción y acrecentamiento, y que, por el contrario, el que no lo diere juzgará que por esto queda en desgracia nuestra ${ }^{50}$.

Si queda alguna duda sobre el control que la Monarquía ejerce sobre los obispos, solo hay que revisar las consultas de los traslados y las medidas que el Consejo toma cuando un prelado se extralimita o viola alguna regalía. Baste como ejemplo lo que

Flórez, E. y otros: España Sagrada..., Madrid, Imprenta Antonio Martín y RAH, 1754-1957, 56 vols.; Zaragoza, L. de, y R. de Huesca.: Teatro histórico de las iglesias del reino de Aragón, Pamplona, Miguel de Esquerez y José Longas, 1780-1807, 9 vols.; Villanueva, J.: Viage literario a las iglesias de España, Madrid, Imprenta Fontaner y RAH,1803-1852), 22 vols., etc.

50 AGS, Estado, leg. 888, fol. 160. 
sucedió a los obispos de Ciudad Rodrigo y de Cuenca. El primero, Manuel de Zúñiga, se atrevió a lanzar graves censuras eclesiásticas contra el corregidor de la ciudad $\mathrm{y}$, aunque era hijo del duque de Béjar, fue castigado con el secuestro de sus temporalidades y el destierro, y solo se le permitió volver a su iglesia después de levantar las censuras y pedir perdón al monarca, pasando el resto de su vida en el pobre obispado de Ciudad Rodrigo sin promover a otro más rico y prestigioso ${ }^{51}$. El segundo, Isidro de Carvajal, que escribió al confesor regio quejándose de la persecución que padecía la Iglesia por las medidas del gobierno, tuvo que comparecer ante el Consejo para reprenderle por sus afirmaciones; se escribió a los demás obispos para informarlos de la imprudente conducta del prelado y decirles que "S. M. escuchará con benevolencia sus manifestaciones, siempre que se le dirijan con la moderación y respeto que era de esperar de su carácter y dignidad episcopal". La lección surtió efecto y ningún prelado quiso exponerse a la mordedura fiscal ${ }^{52}$.

Entre los obispos que rigen las diócesis españolas se encuentran carreras fulgurantes, debidas al favor de la cuna, y otras más lentas y trabajosas debidas al mérito y al apoyo de intercesores poderosos. Al favor de la cuna se deben los nombramientos de los miembros de la familia real que ocupan las principales sedes episcopales en distintos momentos del periodo estudiado. Fernando de Aragón, nieto de Fernando el Católico, gobernó la iglesia de Zaragoza durante los años 1539-1577, donde desarrolló una importante labor pastoral y ejerció un destacado mecenazgo cultual ${ }^{53}$. Jorge de Austria, hijo natural del emperador Maximiliano I de Habsburgo, fue nombrado arzobispo de Valencia en 1538 y en 1541 también de Lieja con retención Valencia. Dos años después marchó a Flandes y en 1544 renunció al arzobispado de Valencia. Su hermano Leopoldo de Austria, también hijo natural de dicho emperador, en 1541 fue nombrado obispo de Córdoba, que entonces era una de las mitras castellanas más ricas $^{54}$. La sede primacial de Toledo la ocuparon cuatro miembros de la familia real: Alberto de Austria, Fernando de Austria, Luis Antonio de Borbón y Luis María de Borbón.También es impulsada por el favor, aunque no en tan desaforada medida, la carrera de algunos miembros de la saga de los Sandoval, gracias al valimiento del duque de Lerma. Otros muchos, merced a la protección de la Corte y a intercesores poderosos, realizan una carrera brillante, pero más lenta y costosa.

Por último, hay que tener en cuenta que la interrelación entre la burocracia eclesiástica y la civil era algo normal en los siglos modernos, sobre todo en el XVI y XVII, y se puede apreciar en el cursus de más de ciento cincuenta obispos, que después de una carrera brillante en la burocracia civil vuelven o pasan a la eclesiástica al ser nombrados obispos ${ }^{55}$.

51 Consulta de la Cámara de Castilla, 5 de julio de 1697, AHN, Consejos, leg. 51349. Nombrado obispo de Ciudad Rodrigo el 21 de marzo de 1695, muere en su iglesia el 14 de diciembre de 1712.

52 Egido, T.: "Memorial ajustado al expediente consultivo sobre el contenido de diferentes cartas del reverendo obispo de Cuenca, 1768", en Ferrer Benimeli, J. A. (ed.): Relación Iglesia-Estado en Campomanes, Madrid, FUE, 2002, pp. 383-408.

53 Miguel García, I.: La Diócesis de Zaragoza en el siglo XVI. El pontificado de don Hernando de Aragón, 15391775, Zaragoza, Cabildo Metropolitano, 2015, 2 vols.

54 Aranda Doncel, J.: "La familia del Emperador: Leopoldo de Austria, obispo de Córdoba (1541-1557)", en Rivero Rodríguez, M. y Álvarez-Ossorio Alvariño, A. (coord..): Carlos V y la quiebra del Humanismo político en Europa, Madrid, Sociedad Estatal para la conmemoración de los centenarios de Felipe II y Carlos V, 2001, vol. 2, pp. $403-424$.

55 Barrio Gozalo, M.: "Rasgos burgueses en la jerarquía española del Antiguo Régimen (1598-1834)", en Enciso Recio, L. M. (ed.): La Burguesía española en la Edad Moderna, Valladolid, Universidad de Valladolid, 1996, vol. 1, pp. 163-181. 


\section{La edad de nombramiento}

Como antes se indicó, los 52 años y medio que se registran como media general en los tres siglos que se analizan, no dejan lugar a dudas respecto a las condiciones de madurez y responsabilidad que se quiere exigir a los ocupantes de sedes episcopales. Esta afirmación se revalúa aún más si se tienen en cuenta los juicios que las gentes de aquella época emitían sobre la concepción habitual respecto a la vejez, ya que para ellos "llegar a los 52 años era raro y le colocaba a uno en la venerable categoría de los ancianos" $"$. Por otra parte, los funcionarios de la segunda mitad del Setecientos no debían tener un criterio muy distinto cuando en la división por edades de la población censada sitúan en el último tramo de la pirámide a todos los "de cincuenta años arriba". El cuadro primero, elaborado con los datos del $93 \%$ de los electos, muestra que la edad media de preconización experimenta una evolución ascendente durante casi todo el periodo, con un nivel de fluctuación relativamente bajo.

Cuadro 1. Edad media de preconización (Índice 100 = Media).

\begin{tabular}{|c|c|c|c|c|}
\hline Periodo & Años & Meses & Días & Índice \\
\hline $1523-1555$ & 50 & 10 & - & 94,9 \\
\hline $1556-1599$ & 51 & 3 & 3 & 95,7 \\
\hline $1600-1649$ & 54 & 1 & 28 & 101,9 \\
\hline $1650-1699$ & 53 & 1 & 21 & 99,2 \\
\hline $1700-1749$ & 53 & 3 & 9 & 99,5 \\
\hline $1750-1799$ & 54 & 6 & 21 & 101,8 \\
\hline $1800-1834$ & 55 & 5 & 4 & 103,5 \\
\hline Media & 52 & 5 & 19 & 100,0 \\
\hline
\end{tabular}

La tendencia central del conjunto de datos fija en algo más de 52 años la edad media a que se nombra a los obispos que rigen las diócesis españolas, aunque se observan pequeñas diferencias de unas a otras. Solo en la diócesis de Toledo la media baja sensiblemente y se sitúa en torno a los 40 años, porque dos arzobispos son nombrados con ocho y diez años. En cambio, la dispersión de edades es relativamente grande. La mayoría absoluta $(70,7 \%)$ son nombrados entre 40 y 59 años; y están bien representados los que acceden entre los 60-69 años, que suman el 23\%; en cambio el porcentaje de los que consiguen la mitra con más de 70 años no llegan al tres por ciento y solo unos pocos son nombrados con menos de treinta, que era la edad mínima legal que se exigía para poder ser obispo. Tres son miembros de la familia real; otros tres, nobles, y los dos restantes son curiales. También hay que señalar que, en general, los regulares propuestos para ocupar sedes episcopales normalmente lo son a una edad más alta que los clérigos seculares.

56 Pérez Moreda, V.: Las crisis de mortalidad en la España Interior. Siglos XVI-XIX, Madrid, Siglo XXI, 1980, pp. 188-189. 


\section{El reclutamiento regional}

En consonancia con la estructura del Estado y el mayor peso que Castilla tuvo dentro del mismo, así como la incidencia de los decretos de Nueva Planta, la mayoría absoluta de los electos son naturales de Castilla (74,7\%), observándose un incremento a lo largo del periodo, pues del 70,6\% que representan en 1523-1699 suben al 80,1 en 1700-1834. Entre ellos predominan los originarios de la Castilla interior y, más en concreto, los de ambas Castillas, seguidos de los andaluces, gallegos, riojanos, vascos, extremeños, asturianos, navarros, montañeses, murcianos y canarios. Los naturales de la Corona de Aragón solo representan el $23 \%$ del total y su presencia disminuye a lo largo del periodo, pues del 26,2\% que suman en 1523-1699 bajan al 18,8 en 1700-1834. Entre ellos predominan los aragoneses, seguidos de los catalanes, valencianos y mallorquines. Por último, encontramos treinta obispos que nacen fuera de España: cuatro en América y uno en Filipinas, quince en Italia, cinco en Portugal, cuatro en Flandes y uno en Austria.

Los cinco que nacen en América y Filipinas son hijos de españoles que estaban desempeñando cargos de gobierno o sirviendo al rey en esos territorios. Entre los quince nacidos en Italia se encuentran seis cardenales de la curia y un capellán del emperador que ocupan sedes españolas durante el reinado de Carlos V. Los ocho restantes son dos hijos de españoles y dos napolitanos, un sardo y un siciliano, un genovés y un piacentino. Los cinco portugueses que rigen diócesis españolas son Esteban Almeida, Pedro Álvarez de Acosta, Andrés de Noronha, Bernardo de Ataide y Jerónimo Mascareñas. Los dos últimos son hijos de nobles portugueses que siguieron fieles a Felipe IV después de la rebelión de 1640. De los cuatro que nacen en Flandes, Jorge y Leopoldo de Austria son hijos naturales del emperador Maximiliano II, Guillermo de Vandenese era capellán de Carlos V y Francisco del Castillo Ventimiglia, hijo del marqués de Villarias. Por último, el archiduque Alberto nació en Austria y se educó en la corte de Felipe II. Los datos del cuadro segundo especifican la región donde nacen los obispos del periodo estudiado.

Cuadro 2. Origen regional de los obispos españoles (expresado en \%)

\begin{tabular}{|l|c|c|c|}
\hline Región & $\mathbf{1 5 2 3 - 1 6 9 9}$ & $\mathbf{1 7 0 0 - 1 8 3 4}$ & Total \\
\hline Corona de Aragón: & 26,2 & 18,8 & 23,0 \\
• Aragón & 10,7 & 9,3 & 10,0 \\
- Cataluña & 8,8 & 4,6 & 7,0 \\
- Mallorca & 0,9 & 1,1 & 0,9 \\
- Valencia & 5,8 & 3,8 & 4,9 \\
\hline Corona de Castilla: & 70,6 & 80,1 & 74,7 \\
- Andalucía y Canarias & 10,4 & 12,0 & 11,1 \\
- Castilla-La Mancha & 16,4 & 17,7 & 16,9 \\
- Castilla y León57 & 30,9 & 26,8 & 29,2 \\
- Extremadura & 3,6 & 4,2 & 3,9 \\
- Galicia y Asturias & 4,5 & 9,4 & 6,6 \\
- Murcia & 0,7 & 2,0 & 1,3 \\
- Navarra y País Vasco & 4,1 & 8,0 & 5,7 \\
\hline
\end{tabular}

57 Incluye también Cantabria y La Rioja. 


\begin{tabular}{|l|c|c|c|}
\hline Otros territorios: & 3,2 & 1,1 & 2,3 \\
\hline Total & 100 & 100 & 100 \\
\hline
\end{tabular}

En segundo lugar, interesa conocer en qué medida se respeta el criterio de la naturaleza a la hora de nombrar obispos para las diócesis de Castilla y Aragón. Hasta principios del siglo XVIII, si exceptuamos el reinado de Carlos I, la casi totalidad de los obispos designados para sedes castellanas son castellanos $(96,2 \%)$, siendo simbólica la presencia de aragoneses $(2,5 \%)$, portugueses y de otros territorios $(1,3 \%)$. Pero, a partir de 1700 , el porcentaje de los castellanos baja un poco (89\%) y sube el de los aragoneses (10,5\%), y ya solo se encuentra un italiano, Julio Alberoni, nombrado obispo de Málaga el 6 de diciembre de 1717.

En las diócesis de la Corona de Aragón la situación es muy diferente. Hasta la abolición de los fueros a principios del siglo XVIII la presencia de naturales es muy elevada $(73,2 \%)$, bien porque algunos territorios, como Aragón y Valencia, tenían fuero que disponía que al menos uno de cada dos obispos electos fuera natural del reino, bien por la política más respetuosa que los Austrias mantuvieron con estos territorios. En consecuencia el número de castellanos que durante este periodo pastorea diócesis aragonesas solo representa el 26,4\%. En cambio, después de la abolición de los fueros, los monarcas empezaron a nombrar mayoritariamente a castellanos para las sedes aragonesas y esto determinó que en el periodo 1700-1834 la presencia de castellanos suba hasta el 67,4\% y la de aragoneses baje al 32,2\%. En conclusión, con los decretos de Nueva Planta y la pretendida uniformidad centralista, "reduciendo todos los reinos de España a la uniformidad de unos mismos usos", cambian las cosas pero a favor de los castellanos. Desaparece el privilegio de extranjería y el monarca nombra mayoritariamente obispos castellanos para las diócesis aragoneses, sin que a cambio los aragoneses reciban obispados en Castilla, tal como se había dado a entender, a guisa de consuelo de la abolición de los fueros. El resultado es que los castellanos continuaron acaparando la casi totalidad de las mitras de Castilla (90\%) y se beneficiaron de la mayoría de las aragonesas (67\%).

\section{Un mundo social diverso}

El estudio del origen social de los electos aparece dificultado por la escasa información que aportan las fuentes consultadas. En los procesos informativos solo la tercera pregunta del primer interrogatorio inquiere sobre los padres del candidato: "si es hijo de legítimo matrimonio, de honestos y católicos padres, y cómo se llaman", sin que demande información sobre su procedencia social. Esto da lugar a que únicamente en los casos de rancia alcurnia los testigos informen con cierta precisión sobre el particular; fenómeno que también se repite en las consultas de la Cámara. En caso contrario, se limitan a decir que sus padres son de las familias ilustres y distinguidas de aquel reino, hijosdalgo notorios y de casa solariega, infanzón que en Castilla se llaman hijosdalgo, de la primera nobleza de aquel valle o montaña, caballeros muy principales y de conocida nobleza, o simplemente informan que son personas principales y cualificadas u honestos católicos, pero recalcando bien su limpieza de sangre, sobre todo en el siglo XVII. En el siglo XVIII ya no se insiste tanto en la limpieza de sangre. Aunque todavía se sigue mencionando la calidad de cristianos viejos, se 
recalca más la honestidad y los servicios prestados al Estado, sin que se olviden de desempolvar las relaciones que les unen con la nobleza.

Algo similar ocurre con los episcopologios y biografías, pues solo cuando pertenecen a los estratos más altos o más bajos de la sociedad, con mayor preferencia hacia los títulos nobiliarios, dan información abundante. Por ejemplo, de Pedro González de Mendoza, que rige las diócesis de Granada, Zaragoza y Sigüenza durante los años 1610-1639, se dice escuetamente que es "hijo del príncipe de Eboli, don Ruy Gómez Silva, y de doña Ana de Mendoza y la Cerda, primeros duques de Pastrana" ${ }^{\text {"58; }}$ en cambio de Antonio Palafox, obispo de Cuenca al inicio del siglo XIX, se informa con más riqueza de detalles ${ }^{59}$.

De acuerdo con los datos que las fuentes consultadas ofrecen sobre el nivel social de $94 \%$ de los obispos electos, los he agrupado en tres clases: miembros de la nobleza titulada $(17,1 \%)$, muchos de los cuales son segundones y, en algunos casos, bastardos; miembros de la nobleza no titulada, es decir de la pequeña y mediana nobleza (42,8\%); y miembros de las clases medias $(40,20 \%)$, entre los que predominan los hijos de labradores acomodados, de la burguesía de las profesiones y de los negocios, a los que se suma una pequeñísima representación de niveles más bajos, según se indica a continuación.

\begin{tabular}{|l|c|c|c|}
\hline \multicolumn{1}{|c|}{ Calidad } & $\mathbf{1 5 2 3 - 1 6 9 9}$ & $\mathbf{1 7 0 0 - 1 8 3 4}$ & TOTAL \\
\hline Nobleza titulada & 22,9 & 10,5 & 17,1 \\
\hline Nobleza no titulada & 40,6 & 43,4 & 41,7 \\
\hline Clases medias & 35,1 & 44,9 & 40,0 \\
\hline Clases bajas & 1,4 & 1,2 & 1,2 \\
\hline
\end{tabular}

Aunque los datos muestran que, a medida que avanza el tiempo, se produce una disminución de los miembros de la nobleza titulada a favor de las clases medias, que cada vez están mejor representadas, las cifras ponen de manifiesto el peso de la nobleza en el nombramiento de prelacías. Por tanto, entre los electos encontramos miembros de todos los estratos nobiliarios, desde el modesto hidalgo montañés hasta las primeras casas de Castilla y Aragón e incluso algunos miembros de la familia real, aunque lo más frecuente es el ascenso de los miembros de la nobleza media.

En el siglo XVI los obispos procedentes de la nobleza titulada están presentes en muchas sedes, pero en mayor número en las castellanas que en las aragonesas. En el XVII su presencia es todavía más acentuada, con la peculiaridad de que los miembros de la primera nobleza se suceden de forma casi ininterrumpida en las sedes más importantes de Castilla. En Toledo inicia el siglo Bernardo de Rojas Sandoval (15991618), tío del duque de Lerma, y lo cierra Luis Fernández de Portocarrero (16771709), hijo de los marqueses de Almenara. Algo similar ocurre en el arzobispado de Sevilla, donde se suceden prelados de rancia estirpe de forma casi ininterrumpida,

58 Minguella, T.: Historia de la diócesis de Sigüenza y de sus obispos, Madrid, Imprenta de la RABM, 1913 , vol. 3, p. 30. Nombrado obispo de Granada el 19 de julio de 1610, el 8 de febrero de 1616 promovió a Zaragoza y el 2 de octubre de 1623 a Sigüenza, donde murió el 23 de julio de 1639.

59 Muñoz y Soliva, T.: Noticias de todos los Señores Obispos que han regido la diócesis de Cuenca, Cuenca, Imprenta Francisco Gómez, 1860, p. 469. 
pues solo aparecen en todo el siglo dos apellidos menos relevantes, pero también de hidalga prosapia: el dominico Pedro Tapia (1652-57) y Antonio Payno (1663-69). El esquema se repite en otras diócesis castellanas importantes como Cuenca, Plasencia o Sigüenza, donde los prelados de la alta nobleza se suceden de forma casi continua. Y, en menor medida, en Burgos, Córdoba, Jaén, Granada, Jaén, Málaga y Santiago, donde terminan su carrera muchos prelados nobles que la habían comenzado por sedes más modestas, como Segovia, Astorga, Ciudad Rodrigo, etc. En las diócesis aragonesas, aunque el porcentaje de obispos de la alta nobleza es más bajo que en las castellanas, también se encuentran apellidos de linajuda estirpe, incluso en las sedes más modestas, como los Borja, Moncada, Palafox, Crespi, Rocaberti, etc.

Muchos de estos prelados son segundones y, en algunos casos, también bastardos de los grandes señores o del monarca. En parte esto es solo un aspecto de la tendencia general a procurar una situación conveniente en la Iglesia a los que por defecto de nacimiento podían encontrar dificultades para situarse en el siglo. Pues, aunque el papa Alejandro III y, después, el concilio de Trento declararon la ilegitimidad impedimento para obtener dignidades episcopales, y los papas sucesivos confirmaron estas disposiciones, la realidad fue muy diferente por la presión de los monarcas. Cuando en 1558 Paulo IV protestó por la presentación de Diego de Córdoba para el obispado de Ávila, vacante por el traslado de Diego de Álava a Córdoba, el cardenal Pacheco defendió su nominación, afirmando que los grandes méritos del electo importaban mucho más que el defecto de nacimiento, porque aunque el tridentino prohibía nombrar obispos a bastardos, no lo hacía de una forma tan absoluta que Su Santidad no pudiera dispensar cuando el candidato era un hombre tan calificado como don Diego ${ }^{60}$. Solo en contadas ocasiones los papas se negaron a confirmar un nombramiento por el hecho de ser bastardo. Sixto V (15801590) fue uno de los pocos pontífices que restringió el acceso de los ilegítimos al episcopado.

Felipe II quiso promover a Pedro de Aragón, bastardo del duque de Segorbe, del obispado de Jaca al más rico de Orihuela, pero el papa rehusó y el monarca tuvo que esperar al pontificado de Clemente VIII para que aceptase su traslado a Lérida en 1592. Algo parecido sucedió con Juan de Zúñiga, presentado al obispado de Canarias, pues Sixto V se negó a preconizarle y tuvo que esperar al reinado de Felipe III para conseguir el obispado de Cartagena ${ }^{61}$. Cuando el año 1596 Felipe II presentó para la mitra de Cádiz a Maximiliano de Austria, hijo natural del archiduque Leopoldo de Austria, el papa Clemente VIII le negó la dispensa de ilegitimidad, "porque su padre había llegado a ser obispo de Córdoba y esta circunstancia podía originar escándalo", pero el rey pidió a su embajador en Roma que insistiera ante el pontífice para conseguir la dispensa, no solo para la sede episcopal de Cádiz, a la que estaba presentado, sino también para cualquier otra iglesia ${ }^{62}$. La Curia se resistió "por el posible escándalo que pudiera originarse al haber sido obispo el padre de Maximiliano y por añadidura bastardo", pero el embajador siguió presionando, diciendo que la ciudad de Cádiz estaba muy distante de Córdoba y que el archiduque Leopoldo

\footnotetext{
60 AGS, Estado, leg. 883. Murió antes de ser preconizado.

61 Preconizado obispo de Cartagena el 23 de enero de 1600, dimite dos años después, al ser nombrado inquisidor general, y muere el 20 de diciembre de 1606.

62 AAV, Arch. Concist., Acta Congr. Consist., vol. 3, fol. 318.
} 
había sido obispo de ella hacía mucho tiempo ${ }^{63}$. Los deseos de Felipe II solo se vieron colmados en parte, pues fue dispensado del impedimento de ilegitimidad únicamente para ser obispo de Cádiz; por ello cuando Felipe III le trasladó a Segovia en 1601 tuvo que solicitar nueva dispensa.

Esto explica que, al examinar el catálogo de los obispos que rigen las diócesis españolas en los siglos XVI y XVII, descubramos un buen número de bastardos de la familia real y de la alta nobleza, aunque a veces se dice de una forma tan discreta en el proceso informativo que casi pasa desapercibido, como sucede con Mendo de Benavides (Segovia, 1633-40), "hijo natural del conde de Santisteban y doña Teresa de Moya, y le hubieron ambos a dos libres y no obligados a religión ni a otro vínculo, y de forma que pudieran contraer matrimonio legítimamente" 64 .

La Curia romana acabó por impacientarse y, con motivo de la petición de dispensa de ilegitimidad para Juan Álvarez Osorio, hijo natural del marqués de Astorga, que había sido presentado a la mitra de León en $1672^{65}$, hizo saber a la regente Mariana de Austria "que teniendo escrúpulos en dispensar bastardías, sería muy del cristiano celo de V. M. que en adelante no proveyese estas dignidades en personas que tuviesen este defecto" $" 66$. Sin embargo en los años siguientes el monarca continuó presentando a bastardos para prelacías y Roma concediendo la dispensa, como sucede con Alfonso de San Martín nombrado obispo de Oviedo en 1675, que era hijo natural de Felipe IV y de una dama de la reina, aunque uno de los testigos que declara en el proceso informativo se limita a decir que es hijo de casado y mujer soltera, "y no pudo decir cómo se llamaron sus padres en atención a la grandeza y el estado del padre, y sabe que nació en el real sitio del Buen Retiro, y también sabe que está dispensado por Su Santidad para poder ordenarse de presbítero"67. Más explícita es la información sobre Francisco Manuel de Zúñiga, presentado a la mitra de Ciudad Rodrigo en 1695, que era hijo natural del duque de Béjar,

que le hubo en una señora doncella noble y de calidad muy conocida, natural de la villa de Béjar, siendo soltera, en cuyo tiempo tan solo era marqués de Valero. Y lo sabe por haberlo oído y por haber visto que dicho señor duque le crío y le trató como tal hijo natural, y lo mismo la señora doña Teresa Sarmiento de la Cerda, con quien casó dicho señor duque y hermana del que declara. $\mathrm{Y}$ en este conocimiento y estimación ha sido habido y tenido, y siempre tratado como tal hermano, así el señor duque de Béjar, que murió en Buda, como el señor marqués de Valero, virrey de Navarra, y la señora condesa de Benavente, todos hermanos e hijos del dicho señor duque don Juan Manuel de Zúñiga. Y así mismo sabe que la madre del dicho Francisco Manuel de Zúñiga se entró religiosa en el convento de la Asunción de la dicha villa de Béjar, donde vivió y murió muy ejemplarmente, y que por los puestos y dignidades que ha tenido en su religión ha sido dispensado ${ }^{68}$.

63 Ibidem, fol. 317. El archiduque Leopoldo murió, siendo obispo de Córdoba, el 27 de septiembre de 1557.

64 AAV, Arch. Concist., Processus Consist., vol. 32, fol. 502.

65 Fue nombrado obispo de León el 12 de diciembre de 1672.

66 Nithard a la Reina, 23 de octubre de 1672, AHN, Consejos, leg. 15266.

67 AAV, Arch. Concist., Processus Consist., vol. 74, fol. 377v. Preconizado obispo de Oviedo en 1775, promovió a Cuenca en 1681 y murió el 5 de julio de 1705. García Fueyo, B.: Alonso Antonio de San Martín, obispo de Oviedo y Cuenca e hijo de Felipe IV, Oviedo, Universidad de Oviedo, 2012.

68 AAV, Arch. Concist., Processus Consist., vol. 89, fol. 147v. 
En el siglo XVIII y primer tercio del XIX, aunque el número de obispos que proceden de la nobleza titulada disminuye sensiblemente, todavía se encuentran bastantes miembros de las primeras casas nobiliarias e incluso de la casa real, como Luis Antonio Jaime de Borbón (Toledo, 1735-54), hijo de Felipe V e Isabel de Farnese, y su hijo Luis María de Borbón (Toledo, 1800-23), "hijo legítimo de legítimo matrimonio del serenísimo señor infante de España don Luis Antonio Jaime de Borbón, arzobispo dimisionario de Toledo y Sevilla, y de la ilustre señora doña María Teresa Vallabriga" ${ }^{69}$. De todas formas, a partir de mediados del siglo XVIII disminuye sensiblemente la representación de los miembros de la aristocracia y, en general, del estamento nobiliario, a la vez que se va incrementando progresivamente el número de los provenientes de las clases medias, de forma que en el primer tercio del siglo XIX ya constituyen la mayoría absoluta de los electos.

Por último, el hecho de que uno pertenezca al estamento noble no significa que tenga un nivel económico elevado. Juan de San Millán, nombrado obispo de Tuy en 1547, era hijo de hidalgos, "ricos de virtudes y pobres de bienes de fortuna", al igual que sucede a Martín Pérez de Ayala, preconizado obispo de Segovia en 1560, que era de noble abolengo, pero carecía de bienes de fortuna ${ }^{70}$. Bernardo de Fresneda, nombrado obispo de Cuenca en 1562, era de familia noble pero muy humilde; etc. En cambio, encontramos labradores acomodados que pueden financiar el estudio de alguno de sus hijos, como es el caso de Antonio Sánchez Sardinero, nombrado obispo de Huesca en 1743.

\section{La formación}

Según lo establecido por los Reyes Católicos y después recuerda Felipe II en la carta que escribe a los prelados en 1578, para que le envíen una relación de los eclesiásticos de sus diócesis que juzguen dignos de ser presentados a prelacías, se requiere "que sean graduados en teología o cánones por universidades aprobadas". Aunque la mayoría de los electos se ha graduado en las universidades, en los últimos años del siglo XVI se critica la endeblez de algunos títulos académicos otorgados por universidades de escasa prestancia u obtenidos por medio del fraude ${ }^{71}$. En la segunda mitad del siglo XVIII se vuelve a insistir sobre las titulaciones universitarias y se pide al monarca que no se considere graduado a ninguno que no reciba su grado en alguna de las universidades mayores de Valladolid, Salamanca y Alcalá, y alguna otra que pareciere conveniente por la pobreza y distancia de algunas provincias y reinos. Incluso se recomienda a las universidades mayores que cumplan estrictamente lo que prescribían sus estatutos sobre la concesión de grados. "Materia en la que han aflojado un poco, reconociendo que con su integridad venían a perder los intereses de los grados, que tiraban a sí las universidades menores, en donde se dispensaba con abuso y demasiada facilidad" 72 .

69 Ibidem, vol. 202, fol. 167. Vázquez García, F.: El Infante Don Luis Antonio de Borbón y Farnesio, Ávila, Institución Gran Duque de Alba, 1990; y Rodríguez López-Brea, C.: Don Luis de Borbón, el cardenal de los liberales (1777-1823), Albacete, Junta de Castilla-La Mancha, 2002.

70 Gutiérrez, C.: Españoles en Trento, Valladolid, CSIC, 1951, p. 775.

71 Obispo de Guadix a Felipe II. Guadix, 8 de mayo de 1596, AGS, Patronato Eclesiástico, leg. 135.

72 Memorias sobre el uso del nuevo Concordato, AGS, Gracia y Justicia, leg. 600, n. 1. 
La casi totalidad de los que acceden al episcopado (el 97\%) han cursado estudios superiores y están graduados. La mayoría $(83,4 \%)$ obtiene el grado en alguna universidad y el resto, todos ellos religiosos, en los centros de estudio de su religión. En consecuencia, más de la mitad de los electos $(58,6 \%)$ está en posesión del grado de doctor, alcanzando así la cumbre de la titulación universitaria; poco más de la quinta parte $(23,1 \%)$ son licenciados, unos pocos $(1,7 \%)$ son bachilleres, la sexta parte $(16,6 \%)$ maestros por su religión y el resto no posee ningún título. La mayoría de los que no están graduados son religiosos: ocho franciscanos, seis jerónimos y tres mínimos no se han graduado porque en su instituto religioso no se usa ni acostumbra, $\mathrm{y}$ de otros siete solo consta que no tienen grados. Entre los seculares dispensados pro defectu gradus hay tres miembros de la familia real ${ }^{73}$, dos cardenales y otros ocho de los que se dice que han estudiado teología y se han ejercitado en cánones, pero no consta que tengan grados.

¿Qué disciplinas estudian? Si nos centramos exclusivamente en los que están graduados, los datos del cuadro quinto ponen de relieve que entre los doctores predominan los teólogos, que representan casi la tercera parte, frente a los juristas que solo alcanzan la cuarta parte. Entre los licenciados destacan los juristas (16\%) frente a los teólogos $(7,1 \%)$. En los bachilleres solo hay tres teólogos frente a dieciocho juristas; en cambio, en los maestros por su religión se aprecia la presencia casi exclusiva de teólogos.

Cuadro 3. Titulación académica (expresada en \%)

\begin{tabular}{|l|c|c|c|}
\hline Grado & Teología & Derecho & Total \\
\hline Doctor & 32,9 & 25,7 & 58,6 \\
\hline Licenciado & 7,1 & 16,0 & 23,1 \\
\hline Bachiller & 0,2 & 1,5 & 1,7 \\
\hline Maestro & 16,5 & 0,1 & 16,6 \\
\hline Total & 56,7 & 43,3 & 100,0 \\
\hline
\end{tabular}

El estar graduado en alguna facultad calificaba a los candidatos al episcopado por tener "la doctrina que se requiere a un obispo para poderlo ser y enseñar a sus diocesanos". De aquí el interés de los testigos que declaran en el proceso informativo de los regulares electos que no poseen grados académicos en dejar bien claro que no los han recibido porque en su religión no se acostumbra, aunque es muy docto y ha sido lector de teología muchos años. Cuando los electos son clérigos seculares que han tenido a su cargo alguna parroquia, los testigos acostumbran a decir que no les consta que tenga ningún grado, pero recalcan que ha estudiado con aprovechamiento en las facultades de teología y cánones.

Los centros donde cursan los estudios superiores y obtienen la titulación académica son las distintas universidades que jalonan la geografía española y algunas extranjeras, donde lo hace el $83,7 \%$ de los que se gradúan, y los centros de estudio de algunas órdenes religiosas, donde lo realiza el resto. El cuadro cuarto indica

73 Son tres arzobispos de Toledo: el archiduque Alberto de Austria, hijo del emperador Maximiliano II; Fernando de Austria, hijo de Felipe III, y Luis Jaime de Borbón, hijo de Felipe V. 
que la mayoría de los electos $(75,8 \%)$ se gradúa en las universidades castellanas de Salamanca, Alcalá y Valladolid, quedando a gran distancia las de Ávila, Granada, Sigüenza y Toledo, etc. En las de Aragón lo hace el 20\% y las mejor representadas son las de Valencia, Huesca y Zaragoza, quedando a gran distancia las de Barcelona, Cervera, etc. El resto se gradúa en universidades italianas, sobre todo en Bolonia, en la portuguesa de Coimbra, en París, México y Lovaina. Sin embargo, algunos inician sus estudios en una de las universidades más prestigiosas, pero el grado de doctor lo consiguen en otra de inferior categoría, tanto por motivos económicos como por el nivel de exigencia.

Cuadro 4. Universidades donde se gradúan (expresado en \%)

\begin{tabular}{|l|c|c|c|}
\hline Universidad & $\mathbf{1 5 2 3 - 1 6 9 9}$ & $\mathbf{1 7 0 0 - 1 8 3 4}$ & Total \\
\hline Corona de Aragón: & $\mathbf{2 0 , 8}$ & $\mathbf{1 9 , 2}$ & $\mathbf{2 0 , 1}$ \\
• Huesca & 5,4 & 4,1 & 4,8 \\
• Valencia & 5,8 & 3,9 & 5,0 \\
- Zaragoza & 2,9 & 3,9 & 3,4 \\
- Otras Univ. & 6,7 & 7,3 & 6,9 \\
\hline - Alcalá & $\mathbf{7 3 , 3}$ & $\mathbf{7 9 , 1}$ & $\mathbf{7 5 , 8}$ \\
- Salamanca & 12,8 & 15,3 & 13,9 \\
- Valladolid & 31,7 & 16,1 & 25,0 \\
- Otras Univ. & 12,2 & 11,2 & 11,7 \\
\hline Otros territorios: & 16,6 & 36,5 & 25,2 \\
\hline Total & 5,9 & 1,7 & 4,1 \\
\hline
\end{tabular}

\section{La experiencia previa}

Un número considerable de los electos proviene de los cabildos catedrales y colegiales, siguen los procedentes de la burocracia civil o eclesiástica, quedan a gran distancia los docentes en cátedras universitarias y seminarios, y los párrocos; en cambio, el número de regulares que promueve al episcopado es bastante elevado. En el cuadro quinto, a través de la relación de los cargos previos de los obispos que rigen las diócesis españolas, se pone de manifiesto que los canales que confluyen en la elección episcopal provienen de fuentes muy diversas, máxime si se tiene en cuenta la fuerte presencia eclesiástica en las instituciones de la monarquía antiguo-regimental. Si a esto se une el que muchos poseen grandes beneficios en catedrales y colegiatas, se descubre una superposición y mezcolanza de funciones que hace difícil encontrar la línea de separación en una realidad ya de por sí confusa ${ }^{74}$.

74 En el cuadro se contabiliza únicamente el cargo que desempeñan en el momento de su nombramiento o el que se ha considerado más importante si poseen varios. 
Cuadro 5. El cursus anterior. Cargos previos (expresado en \%)

\begin{tabular}{|l|c|c|c|}
\hline Cargo & $\mathbf{1 5 2 3 - 1 6 9 9}$ & $\mathbf{1 7 0 0 - 1 8 3 4}$ & Total \\
\hline Clero capitular & 39,8 & 49,7 & 44,0 \\
\hline Inquisición & 14,8 & 7,7 & 11,8 \\
\hline Burocracia civil & 9,3 & 2,7 & 6,5 \\
\hline Burocracia eclesiástica & 6,2 & 11,3 & 8,4 \\
\hline Docencia universitaria & 5,1 & 3,6 & 4,5 \\
\hline Asistencia familia real & 6,4 & 1,6 & 4,3 \\
\hline Pastoral directa & 0,7 & 5,3 & 2,6 \\
\hline Órdenes religiosas & 17,7 & 17,9 & 17,8 \\
\hline Ninguno & - & 0,2 & 0,1 \\
\hline Total & 100 & 100 & 100 \\
\hline
\end{tabular}

El examen del cursus anterior de los clérigos seculares que son nombrados obispos descubre que prácticamente no existe separación entre lo que llamamos carrera eclesiástica y carrera civil, pues con frecuencia pasan de una a otra sin más motivo aparente que la esperanza de mejorar su status social y económico. Este comportamiento, que está muy generalizado hasta mediados del siglo XVIII, luego casi desparece, posiblemente por la imposición de la mentalidad tridentina, que trató de levantar una barrera entre el mundo eclesiástico y el civil, y el avance del espíritu secularizador ${ }^{75}$.

La mayoría de los clérigos seculares que acceden al episcopado poseen algún beneficio capitular en el momento de su preconización, sin que se observen fluctuaciones considerables a lo largo de todo el periodo. Muchos, además del beneficio capitular, acumulan otros cargos y beneficios, y el $44 \%$ solo disponen del beneficio capitular o éste es el más importante en el momento de su nombramiento. Entre los capitulares a los que se abren las puertas del episcopado destacan los canónigos de oficio: magistral, doctoral, lectoral y penitenciario, por este orden. Están bien representadas algunas dignidades catedrales, como los arcedianos y deanes, y también la primera dignidad de las iglesias colegiales, es decir, el abad o prior de las colegiatas: San Ildefonso de la Granja, Roncesvalles, Alcalá la Real o Santander, etc.

En el curriculum del 12\% de los electos figura el desempeño de un cargo inquisitorial en el momento de su promoción. En los siglos XVI y XVII, como consecuencia de la fuerza de esta institución, su representación es más elevada (14,8\%) que en el siglo XVIII y primeras décadas del XIX, en que su porcentaje desciende al 7,7\%. Casi la mitad son miembros del Consejo de Inquisición y el resto desempeña el cargo de inquisidor en alguno de los tribunales de distrito, mayoritariamente peninsulares, aunque también hay alguna presencia de los italianos y americanos. Los tribunales con mayor número de electos son Toledo, Valladolid, Barcelona, Cuenca, Zaragoza, Murcia, Granada, Sevilla, etc. ${ }^{76}$.

\footnotetext{
Información sobre este fenómeno en Barrio Gozalo, op. cit. (nota 55), pp. 163-181.

76 Barrio Gozalo, M.: "Burocracia inquisitorial y movilidad social. El Santo Oficio plantel de obispos (15561820)", en Prado Moura, A. de (ed.): Inquisición y Sociedad, Valladolid, Universidad de Valladolid, 1999, pp. 107-138.
} 
Un porcentaje importante de los electos provienen de la burocracia cortesana, como miembros de alguno de los consejos de la Monarquía, que en ocasiones están gobernados por un obispo, presidentes de las chancillerías de Valladolid y Granada, regentes y oidores de los consejos y audiencias. Entre ellos encontramos once presidentes de consejos, veinte presidentes de las chancillerías de Valladolid, Granada y Santo Domingo, treinta consejeros y un fiscal, cinco regentes, diez oidores y otros cargos subalternos. La burocracia eclesiástica también aporta un número importante $\mathrm{y}$, entre ellos, destacan los obispos auxiliares que promueven a residenciales ${ }^{77}$, los vicarios generales ${ }^{78}$, los auditores del tribunal de la Rota romana o española ${ }^{79}$, etc.

La enseñanza en la universidad es otro cauce tradicional de acceso al episcopado, máxime si a los cincuenta y siete catedráticos de las universidades de Salamanca, Alcalá, Valladolid, Huesca, Zaragoza, etc., que consiguen una mitra, se suman los regulares que desempeñan su labor docente en los centros superiores de las órdenes religiosas y, desde finales del siglo XVIII, los seculares que enseñan en los seminarios conciliares.

La asistencia espiritual y cultural a los miembros de la familia real también facilita el ascenso a una mitra. El cargo de predicador real se convirtió en antesala de un obispado, sobre todo en el reinado de Felipe IV, en que quince predicadores consiguen una mitra en España y otros más en América y territorios italianos ${ }^{80}$. Siguen los confesores ${ }^{81}$ y capellanes de la familia real, y los preceptores o maestros de príncipes e infantes. Por último, el número de párrocos que accede al obispado desde la parroquia es de 34, mayoritariamente de Madrid y unos pocos de Toledo, Valencia, Cuenca, Sevilla y Urgel. Y casi todos consiguen la mitra en la segunda mitad del siglo XVIII y primer tercio del XIX, que es cuando más interés se puso en potenciar el cargo de cura párroco o rector de la parroquia ${ }^{82}$.

Los miembros del clero regular que acceden a una mitra son muy numerosos y representan la cuarta parte de los prelados que rigen las diócesis españolas. La mayoría de ellos desempeña cargos de gobierno en sus institutos religiosos y los restantes se ocupan en la atención espiritual y cultural de la familia real, en el Consejo de Inquisición y en la enseñanza universitaria. Su presencia varía sensiblemente a lo largo del tiempo. En el siglo XVI su porcentaje es bajo $(16,1 \%)$, lo que concuerda con el parecer del confesor de Felipe II, Diego de Chaves, que se opone al nombramiento

77 Font, C. R.: España Sagrada, LI. Los obispos españoles titulares in partibus infidelium o auxiliares en las de España, Madrid, Imprenta de José Rodríguez, 1879.

78 En Francia, desde el reinado de Luis XIV se generaliza la costumbre de que los electos hayan ejercido el cargo de vicario general, de forma que después de 1690 el 70\% de los nombrados han ejercido este cargo y a partir de 1732 la casi totalidad, porque ello permitía conocer su capacidad de gobierno y suficiencia de doctrina. Cf. Vernard, M. (ed.): Histoire du Christianismè des origenes a nos jours, IX: L'âge de raison, 1620/30-1750, París, Desclée, 1997, p. 250.

79 Ríus, J.: “Auditores españoles en la Rota Romana”, Revista Española de Derecho Canónico, 3 (1948), pp. $767-$ 781.

80 Negredo del Cerro, F.: Los predicadores de Felipe IV. Corte, intrigas y religión en la España del Siglo de Oro, Madrid, Actas, 2006, informa del oficio de predicador real y de la carrera que desarrollan.

81 Martínez Peñas, L.: El confesor del rey en el Antiguo Régimen, Madrid, Universidad Complutense, 2007, ofrece una reseña biográfica de los confesores regios.

82 No comparto la afirmación de Cuenca Toribio, J. M.: Sociología de una elite de poder de España e Hispanoamérica contemporáneas (1789-1965), Madrid: Pegaso, 1976, p. 66, de que el porcentaje de los párrocos electos obispos representa el 26\% durante la Década Ominosa, pues de acuerdo con los datos que poseo su porcentaje apenas llega al $6 \%$. 
de religiosos por ser contrario a los cánones ${ }^{83}$. En el XVII la influencia y expansión de los regulares hace subir su presencia casi al $40 \%$ de los electos, pero en el XVIII y primer tercio del XIX se produce un descenso progresivo, tanto por la prevención de Felipe $\mathrm{V}$ ante el excesivo número de regulares que ocupaban mitras ${ }^{84}$ como por la mala prensa que tienen en la segunda mitad del siglo, lo que hace bajar su porcentaje a poco más de la quinta parte de los electos. No obstante, en los años 1824-1834 se incrementó el número de regulares hasta superar el $30 \%$, en consonancia con la preferencia de Fernando VII por el clero regular, menos contaminado por la causa liberal, y también porque la experiencia constitucional del Trienio marcó profundamente a eminentes miembros del clero secular, impidiendo su promoción al episcopado, según informa el nuncio Tiberi al cardenal Bernetti, secretario de Estado de la Santa Sede: "El clero secular después de la revolución no cuenta con muchos eclesiásticos que sean dignos por la probidad y doctrina, o que sean idóneos para el gobierno de las iglesias en tiempos difíciles" ${ }^{85}$. Entre los religiosos que promueven al episcopado predominan los franciscanos y los dominicos, con algo más de sesenta electos cada uno, siguen a gran distancia los benedictinos con cuarenta y dos, los agustinos y mercedarios con veinticinco, los jerónimos con diecinueve, los carmelitas calzados con doce, etc.

\section{La duración de los pontificados y su término}

\section{Duración de los pontificados}

El promedio de duración de los pontificados se sitúa en poco más de trece años, y su comportamiento a lo largo del periodo estudiado es bastante irregular, pues en la primera mitad del siglo XVII experimenta una fuerte caída, luego comienza a recuperarse y a partir de la segunda mitad del XVIII se supera ligeramente el nivel inicial. Llama la atención el hecho de que el pontificado del $40 \%$ de los obispos sea inferior a diez años, aunque es verdad que el del $54 \%$ se mueve entre los diez y los treinta, en una progresión decreciente, y el 5\% restante supera los treinta. Estas cifras se refieren a la duración de toda la carrera episcopal, pero son muchos los prelados que rigen varias diócesis. Por lo general, el nombramiento de un obispo está en relación directa con la importancia socioeconómica de la sede. Si la mitra es arzobispado o rica, lo normal es que sea trasladado de otra menos importante y, en consecuencia, el porcentaje de los prelados nombrados de primera provisión es bajo, como sucede en Burgos, Santiago, Sevilla, Valencia y Zaragoza o Córdoba, Plasencia y Sigüenza, entre otras; en cambio, si las rentas de la mitra son de tipo medio o bajo, el número de los nuevamente provistos aumenta progresivamente, de forma que en las más pobres de Almería, Ceuta, Guadix, Lugo, Mondoñedo, Orense, Solsona o Urgel supera el $90 \%$. De esta forma, si se ponen en relación los niveles socioeconómicos de las mitras con los nombrados de primera provisión, se observa que cuánto más importancia económica o social tiene la sede más bajo es el porcentaje de los nuevamente provistos y viceversa.

83 AHN, Consejos, libro 2726, fols. 129-130.

84 Nota de Clarke, confesor real, 18 de junio de 1743, AGS, Gracia y Justicia, leg. 290.

85 Tiberi a Bernetti, Madrid, 6 de junio de 1833, AAV, Segr. Stato, Esteri, vol. 438. 
La explicación de este fenómeno, que se repite hasta la segunda mitad del Setecientos, se encuentra en la Instrucción de 1588 y en diferentes resoluciones de los monarcas, que mandan a la Cámara que en las consultas para cubrir las vacantes de los arzobispados y obispados mayores se proponga a prelados de otras iglesias. Por lo que respecta a los arzobispos así se hace hasta 1764, en que el rey ordena a la Cámara, a propósito de la provisión de Burgos, Tarragona y Zaragoza, "que sin que haya urgente motivo o necesidad no se consulte obispos". Y lo mismo sucede con los siete obispados mayores en 1759, pues habiendo vacado los de Cuenca y Plasencia el rey manda que "no le proponga para estas mitras prelados de otras iglesias"

Los frecuentes traslados de los prelados encontraron reparos en algunos teólogos, al ser algo opuesto a la tradición eclesiástica, que asimilaba la prelacía a una especie de matrimonio espiritual indisoluble del obispo con su iglesia, y acusan de adulterio a los obispos que tratan de mejorar de sede por medio de un traslado ${ }^{87}$. Y también en la Curia romana, a pesar de los beneficios económicos que le reportaba. El año 1599 el papa Clemente VIII envió un breve a Felipe III, pidiéndole que no hiciese traslados de obispos sin necesidad ${ }^{88}$; pero la carta que el 8 de noviembre de 1617 escribió el secretario de Estado de la Santa Sede al nuncio en Madrid sobre traslados de obispos y escrúpulos del confesor del rey ${ }^{89}$, y los datos anteriores muestran que se continuó practicando la traslación de forma generalizada. Hay que esperar a mediados del siglo para que Felipe IV, por seguir la invitación del pontífice o por frenar el mucho dinero que salía para Roma por el coste de las bulas, ordene a los consejos de Castilla y Aragón, por decreto de 11 de noviembre de 1656, que se excusen los frecuentes traslados de prelados de unas iglesias a otras sin causa justa ${ }^{90}$. Sin embargo, nada cambió En 1681 el nuncio volvió a recordar al monarca que el papa se oponía a que los obispos cambiasen de sede ${ }^{91}$ y Carlos II confirmó el decreto de 1656 en junio de $1689^{92}$, pero los traslados continuaron siendo frecuentes.

En el siglo XVIII el tema de los traslados también suscitó opiniones encontradas. En 1703 el confesor de Felipe V se pronunció a favor de los traslados para cubrir las vacantes de los arzobispados y de las mitras mayores, "como regularmente se ha hecho y es muy conforme a la real orden de 1656 por considerar importantes los ascensos de sujetos ya obispos a estas mitras con el fin de que los prelados de las otras iglesias con esta esperanza se alienten a celar en sus diócesis el servicio de Dios y de V. M"93. En cambio, a mediados del siglo, el confesor real Rávago criticó los abusos de la Cámara de Castilla en los traslados por ser contrarios a los cánones, aunque poco después declaró que podían hacerse con dispensa pontificia, no solo por razones de utilidad o necesidad de la iglesia sino también para remunerar y promocionar a los obispos ${ }^{94}$. Lo cierto es que los Borbones, bien fuera por evitar la salida de dine-

\footnotetext{
AHN, Consejos, leg. 18859.

87 Fernández de Navarrete, F.: Conservación de monarquías y discursos políticos, Madrid, Imprenta Real, 1626 (edic. facs. Madrid, Instituto de Estudios Fiscales - Ministerio de Hacienda, 1982), p. 233.

88 González Dávila, G.: Historia de la vida y hechos del Rey D. Felipe III, Alicante, Biblioteca Virtual Miguel de Cervantes, 2017, libro II, cap. VIII.

89 AHN, Santa Sede, leg. 95.

$90 \quad$ AGS, Gracia y Justicia, leg. 588.

91 AAV, Arch. Nunz. Madrid, vol. 14, fols. 553-554.

92 AGS, Gracia y Justicia, leg. 588.

93 Daubenton a Felipe V. Madrid, 12 de octubre de 1703, Ibidem, leg. 534.

94 AGS, Gracia y Justicia, leg. 588.
} 
ro hacia la Corte romana o por el bien espiritual de los diocesanos, abusaron mucho menos de esta prerrogativa regia, lo que se tradujo en que el porcentaje de obispos que rigen una sola diócesis suba del $48 \%$, que se registra en el siglo XVII, hasta el $70 \%$ en el siglo XVIII. En consecuencia, el carrusel de los obispos en Setecientos, aunque importante, es mucho más bajo que en Seiscientos.

Algunos obispos rechazan el traslado por problemas económicos o pastorales, pero otros lo solicitan al monarca, aunque sea a una diócesis más pobre, para cambiar de clima o recobrar la tranquilidad, como sucede con algunos obispos de Cataluña, que solicitan el traslado para volver a su tierra; porque, al desconocimiento de la lengua y de las costumbres del país, se unía la difícil relación con los cabildos, atentos a la menor distracción para acusarles y desprestigiarles.

\section{El término de la carrera episcopal}

La mayoría absoluta de los obispos nombrados en este periodo (el 94,4\%), termina la carrera episcopal cuando les llega la muerte, y solo un pequeño número la finaliza por renuncia o deposición. Es verdad que algunos otros intentan o amenazan con dimitir, pero no lo llevan a efecto o mueren antes de que llegue la aceptación pontificia. Un tercer grupo se vio forzado a dejar temporalmente su iglesia para seguir el camino del exilio o del destierro por motivos políticos. Sobre los que dimiten o lo intentan y los exiliados diré unas palabras.

La edad media de los obispos que fallecen en el ejercicio del ministerio episcopal supera ligeramente los 66 años y medio y tiene un comportamiento ascendente a lo largo de todo el periodo, acentuándose en los años 1750-1834, en que la media se acerca a los 70 años. Estos datos adquieren su exacta significación si se tiene en cuenta que en España, durante la segunda mitad del siglo XVIII, solo el 14,5\% de los varones sobrepasaba los 50 años y que la esperanza de vida apenas llegaba a los 30 años.

El porcentaje de los que renuncian o son depuestos por la autoridad eclesiástica es muy bajo, pues solo supone el 5,6\%. Las cifras más elevadas se dan en los primeros tercios de los siglos XVIII y XIX, en estrecha relación con los avatares políticos que se suceden. En primer lugar, encontramos dos obispos que son depuestos por su conducta: Julián Ramírez y José Fernández de Toro. El primero era obispo de Guadix (1574-1581) y fue depuesto y recluido de por vida en su convento originario de Uclés, declarando vacante la diócesis ${ }^{95}$. Y el segundo, nombrado obispo de Oviedo el 21 de marzo de 1707, fue depuesto por hereje en $1719^{96}$. También estuvo a punto de correr la misma suerte Diego de Torquemada, obispo de Tuy (1564-1582). Por último, el arzobispo de Toledo Bartolomé de Carranza también fue acusado y procesado por hereje, aunque no fue depuesto, después de un largo y complejo proceso que duró diecisiete años ${ }^{97}$.

95 AAV, Segr. Stato, Spagna, vol. 25, fols. 294-304; Cf. Fernández Collado, A.: Gregorio XIII y Felipe II en la nunciatura de Felipe Sega (1577-1581), Toledo, Estudio Teológico de San Ildefonso, 1991, pp. 274-282.

96 BEESS, ms. 390, fols. 17-27; ASV, Segr. Stato, Spagna, ap. XI/1; Tuñón Escalada, J. J.: Corrientes espirituales en la España del siglo XVIII. El obispo de Oviedo Fernández de Toro, Madrid, Fundación María Cristina Maseaveu, 2016, pp. 129-684.

97 El proceso de Carranza consta de veintidós volúmenes manuscritos, que se custodian en el Archivo de la Real Academia de la Historia, y ha sido publicado por Tellechea Idígoras, J. I.: Fray Bartolomé de Carranza. Documentos Históricos, Madrid, RAH, 1962-2008, 8 vols.; El proceso romano del Arzobispo Carranza, 1567-1576, 
En segundo lugar, se cuentan setenta y un prelados que solicitan y obtienen la renuncia al obispado. La mayoría lo hacen de forma voluntaria y unos pocos por la fuerza de la coacción o de amenazas. Las causas que aducen para solicitar del rey y del papa la aceptación de la renuncia están relacionadas con problemas de edad y salud que les impiden ejercer las funciones de su ministerio pastoral, y también con la imposibilidad de compaginar el ministerio con las obligaciones del nuevo cargo de inquisidor general, presidente del algún consejo de la monarquía u otro oficio cortesano. Unos pocos aducen el deseo de retirarse a un convento o querer dejar el obispado por su lejanía, en el caso de Canarias, o por enfrentamientos con el clero. Tres cardenales pasan a residir a Roma y renuncian a la mitra. Uno dimite por no sentirse inclinado al estado eclesiástico y querer casarse, y dos por causas desconocidas. Los forzados a renunciar por el gobierno, generalmente en connivencia con el nuncio, son diez y ocurren sobre todo en la segunda mitad del siglo XVIII y primer tercio del XIX.

Otro pequeño número de obispos proyectó renunciar al obispado o fue presionado para hacerlo, aunque no se llevó a efecto porque desistieron o se adelantó la muerte. Las causas que aducen para solicitar o insinuar el deseo de abandonar la sede son fundamentalmente razones de salud y edad, sin que falten motivos de índole económica y, en algún caso, de matiz político.

Por último, algunos obispos españoles se vieron precisados a exiliarse de sus diócesis por motivos políticos durante la revuelta catalana de mediados del siglo XVII, la guerra de Sucesión de principios del XVIII y, sobre todo, en las convulsiones políticas que se produjeron en el primer tercio del siglo XIX, pero ninguno renunció a la mitra y casi todos volvieron a la diócesis cuando pasó temporal.

La revuelta catalana de 1640 planteó a los obispos un dilema de fidelidad que resultó trágico para ellos y para la iglesia de Cataluña, aunque hay que distinguir entre la revuelta popular y la rebelión política. En el primer caso, algunos prelados apoyaron al pueblo contra la brutalidad de los soldados del ejército real y se enfrentaron y amenazaron con censuras eclesiásticas a sus jefes cuando la violencia afectó a personas, edificios u objetos religiosos, como hicieron los de Elna y Gerona. En cambio, cuando Claris convocó la Junta general de brazos que consumó la ruptura política con el rey católico, con la separación de Cataluña de la Monarquía española y su integración en Francia, todos los obispos, tanto nacionales como foráneos, permanecieron fieles a Felipe IV y se vieron precisados a abandonar sus iglesias por propia voluntad o por expulsión violenta ${ }^{98}$.

La guerra de Sucesión, que enfrentó a los españoles a principios del siglo XVIII, provocó el exilio de algunos prelados. Unos por de ser fieles a Felipe $\mathrm{V}$ en los territorios controlados por el archiduque y otros por ser partidarios suyos o haber sido nombrados por él. En Cataluña es donde más se acusa el problema, pues los obispos de Gerona, Lérida, Tortosa y Urgel tuvieron que abandonar la sede por permanecer fieles a Felipe V cuando el Principado se pronunció a favor del archiduque; en cambio los de Solsona y Tarragona se adhirieron al archiduque y continuaron en sus iglesias, donde fallecieron en 1708 y 1710. El de Barcelona, que había sido llamado

Roma, Iglesia Nacional Española, 1988; y El Proceso romano del Arzobispo Carranza. Las Audiencias en Sant'Angelo, 1568-69, Roma, Iglesia Nacional Española, 1994.

98 Busquets, Joan: La Catalunya del Barroc vista des de Girona, Gerona, Abadía de Montserrat, 1994, vol. 1, pp. 495-526, analiza los avatares de los obispos durante la revuelta. 
a Madrid por sospecharse que era filo-austriaco, fue desterrado por Felipe V, al igual que sucedió luego a los de Solsona, Vic y Tarragona, nombrados por el archiduque. En las demás regiones el problema fue menor: el de Mallorca fue desterrado por el archiduque, el de Segovia por Felipe V y los de Albarracín y Valencia se pasaron al bando austriaco y murieron exiliados en Viena ${ }^{99}$.

Durante la ocupación francesa a principios del siglo XIX los obispos fueron obligados a jurar fidelidad al rey José I y a escribir pastorales en su apoyo, pero muchos tomaron el camino del exilio para evitarlo. Exactamente veintidós obispos (el $37,9 \%$ ), abandonaron la diócesis a medida que se acercaban las tropas francesas para no jurar fidelidad a José I. Unos se desplazaron hacia el sur, otros se refugiaron en Portugal y Mallorca y algunos anduvieron errantes por los pueblos más apartados de su obispado ${ }^{100}$. Al terminar la guerra y restablecerse el gobierno de Fernando VII solo un obispo residencial se vio obligado a dejar la mitra: el arzobispo de Zaragoza que se había exiliado a Francia. Al obispo de Córdoba, Antonio de Trevilla se le incoó un proceso por infidencia, pero en 1815 se archivó por orden de Fernando VII y continuó en la pacífica posesión de la sede hasta el año 1832 en que murió.

Cuando se restableció el régimen constitucional en marzo de 1820, los liberales tomaron una serie de medidas para eliminar a los obispos que más se distinguían por su credo absolutista. Los de León, Oviedo y Tarazona fueron expulsados de la diócesis por haber firmado el Manifiesto de los Persas en 1814. Los de Valencia y Orihuela fueron exiliados por oponerse a las órdenes del gobierno, y no tardaron en seguirles los de Cádiz, Ceuta y Málaga. Los de Pamplona, Urgel y Solsona se vieron obligados a huir, y los de Lérida y Vic fueron sometidos a prisión, y este último fue asesinado en 1823.

Después de la muerte de Fernando VII la figura del obispo exiliado se generalizó. Los arzobispos de Sevilla, Santiago, Zaragoza y Tarragona padecieron en el destierro. Los obispos de Albarracín, Barbastro, Calahorra, Cartagena, Jaén, Menorca, Palencia, Pamplona, Plasencia, Tortosa y Urgel también fueron obligados a tomar el camino del exilio. Los de Lérida, León y Orihuela huyeron de su sede por temor a las autoridades civiles. Los de Badajoz, Coria, Mallorca y Santander permanecieron presos en la diócesis o con libertad vigilada. Si a los desterrados y privados de libertad se suman los veinticinco prelados que fallecieron entre 1833-1840, resulta que prácticamente solo estuvieron libres once obispos durante todo el periodo $1834-1839^{101}$.

\section{Bibliografía}

Alcaraz Gómez, J. F.: Jesuitas y reformismo. El padre Francisco Rávago (1747-1755), Valencia, Facultad de Teología, 1995.

Alcaraz Gómez, J. F.: "Documentos de Felipe V y sus confesores jesuitas. El cursus episcopal de algunos personajes ilustres del reinado", Revista de Historia Moderna, 15 (1999), pp. 13-42.

99 Barrio Gozalo, op. cit. (nota 3, 2004), pp. 222-235.

100 Barbastro, L.: El episcopado español y el alto clero en la Guerra de la Independencia, 1808-1814, Alicante, Instituto Gil-Albert, 2013, informa de la conducta de los obispos.

101 Cárcel Ortí, V.: Política eclesial de los gobiernos liberales españoles, 1830-1840, Pamplona, Eunsa, 1975, pp. 413-509. 
Álvarez-Coca, M. J.: “La Corona de Aragón. Documentación en el Consejo y Cámara de Castilla (1707-1834): fuentes en el Archivo Histórico Nacional”. Hispania, 49/173 (1989), pp. 895-984.

Aranda Doncel, J.: "La familia del Emperador: Leopoldo de Austria, obispo de Córdoba (1541-1557)", en Rivero Rodríguez, M. y Álvarez-Ossorio Alvariño, A. (coords.): Carlos $V$ y la quiebra del Humanismo político en Europa, Madrid, Sociedad Estatal para la conmemoración de los centenarios de Felipe II y Carlos V, 2001, vol. 2, pp. 403-424.

Artola Renedo, A.: De Madrid a Roma. La fidelidad del obispado en España (1760-1833), Gijón, Trea, 2013.

Azcona, T. de: "Derecho de patronato y de presentación a la iglesia de Pamplona. Privilegio de Adriano VI a Carlos V en 1523", Scripta Theologica, 16 (1984), pp. 499-542.

Azcona, T. de: "El hecho episcopal hispánico en tiempo de Carlos V (1516-1558)", en Revuelta Sañudo, M. y Morón Arroyo, C. (ed.): El erasmismo en España, Santander, Sociedad Menéndez Pelayo, 1986, pp. 265-288.

Barbastro, L.: El episcopado español y el alto clero en la Guerra de la Independencia, 18081814, Alicante, Instituto Gil-Albert, 2013.

Barrio Gonzalo, M.: El Real Patronato y los obispos españoles del Antiguo Régimen (15561834), Madrid: Centro de Estudios Políticos y Constitucionales, 2004.

Barrio Gonzalo, M.: La Santa Sede y los Obispos españoles en el Trienio Liberal y el inicio de la reacción (1820-1825), Roma, Iglesia Nacional Española, 2017.

Barrio Gonzalo, M.: "La política vaticana y el nombramiento de obispos en España al final del antiguo régimen", en Liberalisme Chretien et Catholicisme Liberal en Espagne, France et Italie dans la premier moite du XIXe siècle, Aix-en-Provence, Université de Provence, 1989, pp. 175-200.

Barrio Gonzalo, M.: "Rasgos burgueses en la jerarquía española del Antiguo Régimen (15981834)", en Enciso Recio, L. M. (ed.): La Burguesía española en la Edad Moderna, Valladolid, Universidad de Valladolid, 1996, vol. 1, pp. 163-181.

Barrio Gonzalo, M.: "Burocracia inquisitorial y movilidad social. El Santo Oficio plantel de obispos (1556-1820)", en Prado Moura, A. de (ed.): Inquisición y Sociedad, Valladolid, Universidad de Valladolid, 1999, pp. 107-138.

Barrio Gonzalo, M.: "La jerarquía eclesiástica en la España Moderna. Sociología de una elite de poder (1556-1834)", Cuadernos de Historia Moderna, 25 (2000), pp. 17-59.

Barrio Gonzalo, M.: "Sociología del alto clero en la España del siglo ilustrado", Manuscrits, 20 (2002), pp. 29-59.

Barrio Gonzalo, M.: "Estudio socioeconómico de los obispos de Canarias durante el Antiguo Régimen (1556-1834)", Anuario de Estudios Atlánticos, 48 (2002), pp. 1-69.

Barrio Gonzalo, M.: "Perfil socio-económico de los obispos del reino de Valencia durante el Antiguo Régimen (1556-1834)", Anthologica Annua, 50 (2003), pp. 311-371.

Barrio Gonzalo, M.: "Los obispos de Cataluña durante el Antiguo Régimen (1556-1834)", Anthologica Annua, 53-54 (2006-2007), pp. 377-527.

Barrio Gonzalo, M.: "La lucha por el control de los nombramientos episcopales en España al final del Antiguo Régimen (1808-1834)”, Anthologica Annua, 59 (2012), pp. 253-295.

Brandi, K.: "Beriche und Studien zur Geschichte Karl V", Nachrichten von der Akademie der Wissenschaften in Göttingen, 9 (1941), pp. 168-181.

Busquets, Joan: La Catalunya del Barroc vista des de Girona, Gerona, Abadía de Montserrat, 1994.

Cabrera de Córdoba, L.: Historia de Felipe II, Rey de España, Madrid, Sucesores de Rivadeneyra, 1876. 
Cárcel Ortí, V.: Politica eclesial de los gobiernos liberales españoles, 1830-1840, Pamplona, Eunsa, 1975.

Carlos Morales, C. J. de: "La participación en el gobierno a través de la conciencia regia: fray Diego de Chaves, confesor de Felipe II”, en Rurale, F. (a cura di): I religiosi a Corte. Teologia, política e diplomacia in Antico Regime, Roma, Bulzoni, 1998, pp. 131-157.

Castillo de Bobadilla, J.: Política para corregidores y señores de vasallos, en tiempos de paz y de guerra, y para jueces eclesiásticos..., Madrid, Imprenta Real, 1775.

Cuenca Toribio, J. M.: Sociología de una elite de poder de España e Hispanoamérica contemporáneas (1789-1965), Madrid, Pegaso, 1976.

Egido, T.: "Memorial ajustado al expediente consultivo sobre el contenido de diferentes cartas del reverendo obispo de Cuenca, 1768", en Ferrer Benimeli, J. A. (ed.): Relaciones Iglesia-Estado en Campomanes, Madrid, FUE, 2002, pp. 383-408.

Fernández Alonso, J.: "Un periodo de relaciones entre Felipe V y la Santa Sede (1709-1717)", Anthologica Annua, 3 (1955), pp. 43-54.

Fernández Collado, A.: Gregorio XIII y Felipe II en la nunciatura de Felipe Sega (15771581), Toledo, Estudio Teológico de San Ildefonso, 1991.

Fernández de Navarrete, F.: Conservación de monarquías y discursos políticos, Madrid, Imprenta Real, 1626 (edición facsímil, Madrid, Instituto de Estudios Fiscales - Ministerio de Hacienda, 1982).

Fernández, R.: "Historia social. Historia en construcción. Una década de Historia Social en el modernismo catalán”, en Martínez Shaw, C. (ed.), Historia moderna. Historia en construcción, Lleida, Milenium, 1999, vol. 2, pp. 7-54.

Flórez, E. y otros: España Sagrada..., Madrid, Imprenta Antonio Martín y RAH, 1754-1957, 56 vols.

Font, C. R.: España Sagrada, LI. Los obispos españoles titulares in partibus infidelium o auxiliares en las de España, Madrid, Imprenta de José Rodríguez, 1879.

Fuente Cobos, C. de la: "La documentación sobre el patronato eclesiástico de Castilla", Hispania Sacra, 47 (1995), pp. 625-679.

García Fueyo, B.: Alonso Antonio de San Martín, obispo de Oviedo y Cuenca e hijo de Felipe $I V$, Oviedo, Universidad de Oviedo, 2012.

García Marín, J.: La burocracia castellana bajo los Austrias, Sevilla, Instituto García Oviedo, 1976.

González Dávila, G.: Historia de la vida y hechos del Rey D. Felipe III, Alicante, Biblioteca Virtual Miguel de Cervantes, 2017.

González Dávila, G.: Teatro Eclesiástico de las Iglesias metropolitanas y catedrales de los reinos de las dos Castillas, Madrid, en la imprenta de Francisco Martínez, Pedro de Horma y Villanueva, Diego Díaz de la Carrera, 1645-1650, 3 vols.

Gutiérrez, C.: Españoles en Trento, Valladolid, CSIC, 1951.

Hernández, J.: La gestión política y el pensamiento reformista del conde de Floridablanca, Murcia, Editum, 1984.

Hierarchia Catholica Medii et Recentioris Aevi, Monasterii, Regensbergianae, 1923-1968, vols. III-VII.

López Arandia, M. A.: "El confesionario regio en la Monarquía hispánica del siglo XVII", Obradoiro de Historia Moderna, 19 (2010), pp. 249-278.

Martínez Peñas, L.: El confesor del rey en el Antiguo Régimen, Madrid, Universidad Complutense, 2007.

Mercati, A.: Raccolta di concordati su materie ecclesiastiche tra la Santa Sede e le Autoritá Civili, Città del Vaticano, Tipografia Poliglotta Vaticana, 1954, vol. I. 
Miguel García, I.: La Diócesis de Zaragoza en el siglo XVI. El pontificado de don Hernando de Aragón, 1539-1775, Zaragoza, Cabildo Metropolitano, 2015, 2 vols.

Minguella, T.: Historia de la diócesis de Sigüenza y de sus obispos, Madrid, Imprenta de la RABM, 1913, vol. 3.

Müller, W.: “L'episcopat polonais à l'epoque post-tridentine", en Vogler, B. (ed.): L'institution et les provoirs dans les églises de l'antiquité a nos jours, Bruxelle - Louvain, Éditions Nauwelaerts ,1987, pp. 373-382.

Muñoz y Soliva, T.: Noticias de todos los Señores Obispos que han regido la diócesis de Cuenca, Cuenca, Imprenta Francisco Gómez, 1860.

Negredo del Cerro, F.: Los predicadores de Felipe IV. Corte, intrigas y religión en la España del Siglo de Oro, Madrid, Actas, 2006.

Novísima Recopilación de las leyes de España, Madrid, 1805 (ed. facs. Madrid: Boletín Oficial del Estado, 1976).

Pérez Moreda, V.: Las crisis de mortalidad en la España Interior. Siglos XVI-XIX, Madrid, Siglo XXI, 1980, pp. 188-189.

Péronet, M.: Les Èveques de l'ancienne France, Lille, Université de Lille III, 1977.

Ríus, J.: “Auditores españoles en la Rota Romana", Revista Española de Derecho Canónico, 3 (1948), pp. 767-781.

Rizler, R.: "Procesos informativos de los obispos de España y sus dominios en el Archivo Vaticano", Anthologica Annua, 4 (1956), pp. 465-498.

Rodríguez López-Brea, C.: Don Luis de Borbón, el cardenal de los liberales (1777-1823), Albacete, Junta de Castilla-La Mancha, 2002.

Tellechea, J. I.: El Obispo ideal en el siglo de la Reforma, Roma, Iglesia Nacional Española, 1963.

Tellechea Idígoras, J. I.: El proceso romano del Arzobispo Carranza, 1567-1576, Roma, Iglesia Nacional Española, 1988.

Tellechea Idígoras, J. I.: El Proceso romano del Arzobispo Carranza. Las Audiencias en Sant'Angelo, 1568-69, Roma, Iglesia Nacional Española, 1994.

Tellechea Idígoras, J. I.: Fray Bartolomé de Carranza. Documentos Históricos, Madrid, RAH, 1962-2008, 8 vols.

Tuñón Escalada, J. J.: Corrientes espirituales en la España del siglo XVIII. El obispo de Oviedo Fernández de Toro, Madrid, Fundación María Cristina Maseaveu, 2016.

Valladares, A.: Semanario Erudito, Madrid, Blas Román, Madrid, 1787-1791.

Vázquez García, F.: El Infante Don Luis Antonio de Borbón y Farnesio, Ávila, Institución Gran Duque de Alba, 1990.

Vernard, M. (ed.): Histoire du Christianismè des origenes a nos jours, IX: L'âge de raison, 1620/30-1750, París, Desclée, 1997.

Villanueva, J.: Viage literario a las iglesias de España, Madrid, Imprenta Fontaner y RAH, 1803-1852, 22 vols.

Zaragoza, L. de, y R. de Huesca.: Teatro histórico de las iglesias del reino de Aragón, Pamplona, Miguel de Esquerez y José Longas, 1780-1807, 9 vols. 